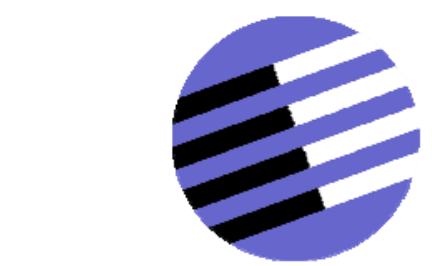

GOVERNANCE AND THE EFFICIENCY

OF ECONOMIC SYSTEMS

GESY

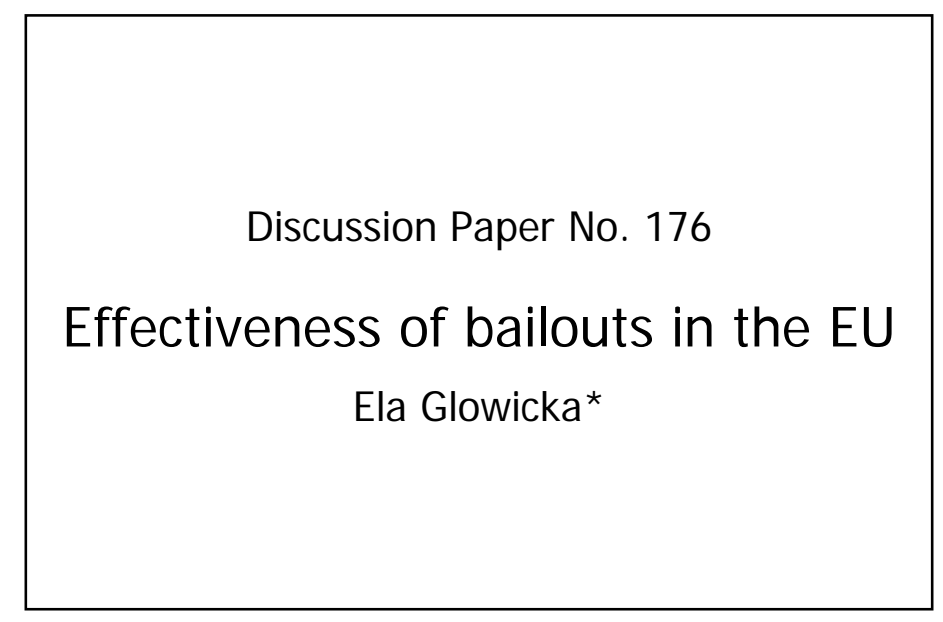

October 2006

*Ela Glowicka, Wissenschaftszentrum Berlin, Reichpietschufer 50, 10785 Berlin, Germany. glowicka@wz-berlin.de

Financial support from the Deutsche Forschungsgemeinschaft through SFB/TR 15 is gratefully acknowledged. 


\title{
Effectiveness of bailouts in the EU *
}

\author{
Ela Głowicka ${ }^{\dagger}$
}

October 2006

\begin{abstract}
Governments in the EU frequently bail out firms in distress by granting state aid. I use data from 86 cases during the years 1995-2003 to examine two issues: the effectiveness of bailouts in preventing bankruptcy and the determinants of bailout policy.

The results are threefold. First, the estimated discrete-time hazard rate increases during the first four years after the subsidy and drops after that, suggesting that some bailouts only delayed exit instead of preventing it. The number of failing bailouts could be reduced if European control was tougher. Second, governments' bailout decisions favored state-owned firms, even though state-owned firms did not outperform private ones in the survival chances. Third, subsidy choice is an endogenous variable in the analysis of the hazard rate. Treating it as exogenous underestimates its impact on the bankruptcy probability. Several policy implications of the results are discussed in the paper.
\end{abstract}

Keywords: State aid; European Union; Discrete-time hazard; Bivariate probit. JEL Classification: K2; G3; L5.

${ }^{*}$ The paper has greatly benefited from discussions with Lars-Hendrik Röller, Tomaso Duso, Hans Friederiszick, participants of EARIE conference 2006 and BDPEMS 2006 workshop on analytical writing. I am grateful for access to data resources of the Directorate General Competition of European Commission and the Economics Department of Vienna University.

${ }^{\dagger}$ E-mail: glowicka(at)wz-berlin.de. Postal address: Wissenschaftszentrum Berlin, Reichpietschufer 50, 10785 Berlin, Germany. 


\section{Contents}

1 Introduction 1

2 Rescue and Restructuring state aid in the European state aid control 6

2.1 State aid in the EC Treaty . . . . . . . . . . . . . . . 6

2.2 Community Guidelines on State Aid for Rescuing and Restructuring Firms in Difficulty . . . . . . . . . . . . . . . . . 8

2.3 Summary statistics . . . . . . . . . . . . . . . . . . . . . . 10

$\begin{array}{lll}3 & \text { Exit patterns for bailed-out firms } & 17\end{array}$

3.1 Non-parametric estimation of exit patterns . . . . . . . . . . . . . . . . 19

3.2 Parametric hazard rate estimation . . . . . . . . . . . . . . . . 21

3.3 Policy implications . . . . . . . . . . . . . . . . . . . . . . . . 29

4 Industrial policy: how governments bail out 33

4.1 Industrial policy . . . . . . . . . . . . . . . . . . . 34

4.2 Endogenous subsidy choice . . . . . . . . . . . . . . . . . . . . . 39

5 Conclusions $\quad 43$

$\begin{array}{ll}\text { References } & 44\end{array}$

$\begin{array}{ll}\text { A Industry classification } & 46\end{array}$

B Data set description $\quad 46$

$\begin{array}{ll}\mathrm{C} \text { Basic definitions in survival analysis } & 47\end{array}$ 


\section{List of Figures}

1 The Commission investigates aid's compatibility with the common market in cases left to its discretion. . . . . . . . . . . . . . . . . 8

2 Empirical hazard function. . . . . . . . . . . . . . . . . . 21

3 Predicted hazard functions for the first 7 years. . . . . . . . . . . . . 28

\section{List of Tables}

1 Year of granting R\&R subsidy. . . . . . . . . . . . . . . . . 11

2 Differences between subsidy types. . . . . . . . . . . . . . . . . 12

3 Differences across countries. . . . . . . . . . . . . . . . . . 14

4 Countries' bailouts per industry. . . . . . . . . . . . . . . . . 15

5 Time-invariant firm characteristics. . . . . . . . . . . . . . . 16

6 Other firm characteristics. . . . . . . . . . . . . 16

$7 \quad$ Description of survival data. . . . . . . . . . . . . . . . . . . . . . . 19

8 Life-table estimates. . . . . . . . . . . . . . . . . 20

9 Estimates of the marginal effects on the hazard rate. . . . . . . . . . 26

10 European bailout control. . . . . . . . . . . . . . . . . . 32

11 Estimates of marginal effects in industrial policy equation. . . . . . . . . . 37

12 Estimates of coefficients in the bivariate probit model. . . . . . . . . . . . . 41

13 Two-digit NACE classification. . . . . . . . . . . . . 46

14 Variables used and their sources. . . . . . . . . . . . . . . . . . 47 


\section{Introduction}

The objective of this paper is to investigate the effectiveness of bailouts in the European Union (EU). Bailouts in the EU are pursued by governments in order to save endangered jobs, support development in certain regions, or promote a certain type of economic activity. Such subsidies also have an impact on competition in the European common market, therefore the European Commission strictly controls them: whenever a government wants to bail out a firm, it must get an approval from the Commission. I examine the effectiveness of bailouts in maintaining survival of firms in distress and I assess European bailout control from this perspective. I also provide empirical evidence on the criteria used by governments in their bailout decisions.

The reasons why some governments bail out are often of political nature. Helping a firm in trouble draws media attention and voters' sympathy, as in the case of Germany's chancellor, Gerhard Schröder, who gained on political support after bailing out the construction firm Philipp Holzmann. ${ }^{1}$ Potentially, there are also economic reasons for bailouts. Due to time-inconsistency of their objectives, governments may lack commitment to a hard no-bailout policy and thereby create soft-budget constraints for firms (Boadway et al., 1995). This is particularly likely in the case of state-owned firms, where there is no separation of ownership and creditor rights (Lin et al., 1998) and where social goods are often produced (Röller and Zhang, 2005). If a failing firm is a monopolist in providing statewide services necessary for economic activities, e.g. railways, a bailout may be needed to avoid a large negative externality on the whole economy (Segal, 1998). A bailout might also be a part of the strategic trade policy with the aim of increasing the market power of domestic firms, at the cost of competing firms from other countries (Głowicka, 2005; Neary, 1994). Finally, if the bankruptcy results in many lost jobs in a region with high unemployment, a bailout might be socially justified.

Bailouts are frequently undertaken by EU governments ${ }^{2}$ and paid with tax revenues.

\footnotetext{
${ }^{1} \mathrm{~A}$ good illustration of the perception of this decision is a title page of Tageszeitung on the day after the bailout decision, Nov. 26, 1999: "Holzmann bails out Schröder" ("Holzmann saniert Schröder"), suggesting that it was actually Schröder's political career which was bailed out.

${ }^{2} \mathrm{~A}$ bailout does not need to be a transfer of resources, it may also be a soft position in debt recovery. For example, when firms in a deteriorating condition do not pay taxes or social security obligations and
} 
Between 1992 and 2003, 79 firms in difficulty were supported by European governments with the aid often expressed in billions of euros. ${ }^{3}$ Governments support firms for a short period of time to help them work out a plan of further action (rescue aid) or they subsidize the restructuring process in the firm (restructuring aid). Every bailout decision must be notified to the European Commission. This is required, because a bailout is a highly selective subsidy: its recipient is one specific inefficient firm, which cannot stay in the market without public support. This kind of aid is likely to distort competition, since it acts directly against competitive forces, which led to the risk of exit. Such practices are forbidden in the EU by the European competition law, but they can be granted an exemption according to the Article 87 of the EC Treaty. Here, countries' industrial policies and EU's competition policy meet and engage in a battle: governments bail out firms of their choice pursuing their own unilateral policies, but the Commission forbids the aid if it adversely affects fair competition in the common market. Bailouts in particular are regulated by the Community Guidelines on State Aid for Rescuing and Restructuring Firms in Difficulty ${ }^{4}$ and in the EU terminology are called rescue and restructuring (R\&R) aid. The European state aid control is now under a "comprehensive, coherent and farreaching reform" with an objective of "less and better targeted state aid." 5 More economic approach to aid control is introduced in several state aid areas (Friederiszick et al., 2006). For this process, a better understanding of how $\mathrm{R} \& \mathrm{R}$ subsidies have worked in the past is crucial.

Bailout control takes place only in Europe, as there is no equivalent bailout policy in the United States. A recent exception is perhaps the Air Transportation Stabilization Board created by the Congress in 2001 with the objective of supporting airlines survival

public institutions are more patient in recovering the debt than a private creditor would be, the firm gets an advantage over its competitors. This was the main issue in the case C-276/02 in the European Court of Justice, as discussed in Nicolaides and Kekelekis (2005).

${ }^{3}$ For example, in 2002 Bankgesellschaft Berlin AG received EUR 9,7 bn rescue and restructuring aid, while the total aid, less agriculture and railways, granted by $15 \mathrm{EU}$ member states amounted to EUR 49 bn.

${ }^{4}$ OJ C 244, 1.10.2004, p.2.

${ }^{5}$ Reforming Europes State Aid Regime: An Action Plan for Change, speech by Neelie Kroes, who is a Member of the European Commission in charge of Competition Policy, during the Wilmer Cutler Pickering Hale and Dorr and the University of Leiden joint conference on European State Aid Reform. Brussels, 14th June 2005. 
after the terrorist attacks on the World Trade Center. Vig (2004) describes the activities of this Board as a dismal failure, since none of the big carriers took part in the loan guarantee program announced by the Board. The reason was that the carriers did not want to give away equity stakes in return for the bailout, which was one of the conditions of getting the loan. This outcome is a warning that subsidizing firms in difficulty is not an easy task.

I analyze R\&R aid granted to 79 firms from 10 EU countries during the years 19922003. The list of bailed-out firms is fixed and I collect additional information on these firms, which makes it a unique data set. The additional information comes from four sources: decision texts of the Commission, London Economics (2004) report to the Commission, the AMADEUS data base and newspapers. The research objective is to examine if bailouts in the EU have achieved their goals. The goal of a bailout is preventing firm's bankruptcy. A bankruptcy (or exit) is defined as ceasing operations of a firm. If a firm becomes insolvent, sells most of their assets, reduces employment dramatically and stays active in the market, it is also counted as bankrupt.

I study three issues. First, I ask the question: how did the risk of bankruptcy change after the bailout? To provide an answer, I estimate the hazard rate of all $\mathrm{R} \& \mathrm{R}$ aid beneficiaries. The results show that in the first four years after the bailout firms exit at an increasing rate. This indicates that a bankruptcy after the bailout does not occur randomly, but is a result of a wasteful behavior: firms went bankrupt with delay, because they could afford to survive a bit longer with the means granted by the state. A total of $29.3 \%$ of the subsidized firms exit anyway. Predictions from the hazard equation suggest that the Commission could have reduced this failure rate by prohibiting rescue aid in sectors with small externalities for the economy. The required standard of proof in the Commission's bailout approvals should be at least a $70 \%$ chance of survival for four years after the bailout.

Second, I find that firms receiving a restructuring subsidy go bankrupt less often than rescue aid receivers. Allocation of these two types of aid to different firms is therefore a tool for discrimination. The results on the choice of subsidy type suggest that state-owned 
firms receive restructuring aid with higher probability due to governments' preference for public employment. Once I control for public employment, being a state-owned firm becomes a disadvantage in chances for restructuring aid. All state-owned firms which were later privatized received exclusively restructuring aid, as well as state-owned firms older than 100 years. This special position of state-owned firms is likely to cause soft budget constraints in state-owned enterprizes in Europe. I also find a strong time trend in the data: after the year 2000 rescue aid was more likely than restructuring aid, while the opposite is true for the years up to 2000. This is likely to be a result of the political campaign at the European level to reduce R\&R aid, which started with the Lisbon Agenda in 2000. As a consequence of this tendency, however, more firms are granted aid which is less efficient in preventing bankruptcy.

Third, I reject the hypothesis that the subsidy type is exogenous in the hazard estimation. Governments select firms that get more comprehensive restructuring aid and influence the firm's survival chances by this choice. The impact of the endogenous subsidy type on the hazard rate is stronger than in the case of the exogenous subsidy type. Thus, without taking the endogeneity into account, the effect of the subsidy type on the hazard is underestimated.

The literature most relevant for this paper are empirical studies on bankruptcy prediction. Such studies typically use firm-level accounting data to predict duration of Chapter 11 protection in the American bankruptcy law. Shumway (2001) advocates survival analysis as the most appropriate econometric technique to predict bankruptcy. Bandopadhyaya (1994) finds the counterintuitive result that the higher the outstanding interest of the firm, the earlier the firm gets over its difficulties. His explanation is that creditors are more willing to compromise in negotiations when the debt is high. Li (1999) develops a Bayesian approach to hazard estimation. In both papers, the probability of exiting Chapter 11 protection increases during the first two years. My result is exactly opposite: the probability of bankruptcy increases with time during the first four years.

Both R\&R aid and Chapter 11 have the same aim: to prevent bankruptcy. Couwenberg (2001) estimates that $41 \%$ of firms under Chapter 11 protection during the years 1980 - 
1996 restructure successfully and come back to vitality. Looking at major cases, however, the success rate is close to $100 \%(\mathrm{Li}, 1999)$. These numbers are achieved without any transfers from the state to the firms in trouble. For R\&R aid during the years 1995-2003, the share of survivors amounts to $70.7 \%$. This outcome suggests that there is scope for improvement in the European bailout policy. The crucial difference between Chapter 11 protection and $R \& R$ aid is the incentives they create. Managers avoid Chapter 11 ex ante, since the likely outcome of starting bankruptcy proceedings is that creditors will get a part of the equity. In addition, under Chapter 11 protection firms incur legal and opportunity costs. R\&R aid, in turn, requires no transfers of equity to creditors. The firm gets a transfer from the taxpayers, which allows firms to continue operations. Thus, the incentives of European managers to avoid bankruptcy are not as strong. Therefore, I provide empirical support for the suggestion of Nitsche and Heidhues (2006) that R\&R aid should be linked to bankruptcy proceedings, for example by granting aid only to firms that formally file for bankruptcy. Such a condition would have more severe consequences for managers who failed to restructure the firm earlier, since it signals managers' failure to the market. Managers would then have stronger incentives not to ask for aid.

Papers evaluating state aid programs are more and more popular (for an overview see Heckman (2001)), but concerning bailouts in the EU the only empirical analysis was done by Chindooroy et al. (2005) (based on the LE report (2004) by the same authors). Their paper provides summary statistics about the cases and a discrete choice estimation of survival probability. They find that about $30 \%$ of $R \& R$ aid beneficiaries went bankrupt, which they attribute to the business cycle. My paper is different from theirs in several ways. Since hazard models give better survival probability estimates (Shumway, 2001), I use the hazard approach. ${ }^{6}$ It allows me to compare R\&R aid to the Chapter 11 protection, for which the hazard rate estimates exist already. I also analyze governments' bailout policies, which is an entirely new research topic. Finally, I investigate the interdependence between the subsidy choice and bankruptcy.

The paper is organized as follows. The next section describes the legal framework

\footnotetext{
${ }^{6}$ Jenkins (2004) provides an excellent guide to discrete-time hazard rate estimation.
} 
for bailouts in the EU and provides some summary statistics on how the guidelines were applied during the years 1995-2003. Next, I estimate the hazard rate of R\&R aid beneficiaries, compare it to Chapter 11 hazard rates and assess the effectiveness of bailouts in preventing bankruptcy. In section 4, I empirically examine governments' choices to grant rescue versus restructuring aid and I explore the endogeneity of the subsidy choice in the hazard rate analysis. Finally, I sum up in the last section.

\section{Rescue and Restructuring state aid in the Euro- pean state aid control}

\subsection{State aid in the EC Treaty}

Article 87 (1) of the EC Treaty ${ }^{7}$ provides legal constraints to state aid in the EU. State aid is incompatible with the common market, and therefore in general prohibited, when it fulfils four conditions: it is granted from state resources, distorts or threatens to distort competition, favors certain undertakings, and affects trade between member states. If one of the conditions is not satisfied, state aid law does not apply. For example, European subsidies for farmers are not incompatible, since the selectivity condition is not fulfilled: all farmers receive them. If a local ferry between islands of the same country is subsidized, trade between member states is not affected and the European state aid law does not apply. But when the ferry connects two different member states, the aid is incompatible with the common market. Only three types of aid are per se considered compatible (Article $87(2))$ : social aid granted to individuals which does not discriminate with respect to the origin of the products, aid to remedy natural disasters and aid to compensate economic disadvantages of the the division of the Federal Republic of Germany in the last century.

Article 87 (3) gives the Commission discretion to grant exemptions to state aid prohibition in five cases:

a) aid to promote the economic development of areas where the standard of living is abnormally low or where there is serious underemployment;

\footnotetext{
${ }^{7}$ OJ C 325, 24.12.2002, p.67.
} 
b) aid to promote the execution of an important project of common European interest or to remedy a serious disturbance in the economy of a Member State;

c) aid to facilitate the development of certain economic activities or of certain economic areas, where such aid does not adversely affect trading conditions to an extent contrary to the common interest;

d) aid to promote culture and heritage conservation where such aid does not affect trading conditions and competition in the Community to an extent that is contrary to the common interest;

e) such other categories of aid as may be specified by decision of the Council acting by a qualified majority on a proposal from the Commission. ${ }^{8}$

Article 88 makes the European Commission and the member states responsible for the control of the compatibility of all state aid measures in the EU. Governments should notify the Commission about state aid measures they plan to take and they must take the opinion of the Commission about aid compatibility with the common market into account when deciding on the aid. Third parties can submit their comments on government aid. Finally, if illicit aid was granted, the Commission can demand the aid to be altered, abolished or repaid.

Article 89 gives the Council the right to introduce regulations about the implementation of Article 87 and 88, as well as exemptions from the regulations. An important block exemption is a de minimis rule, ${ }^{9}$ which states that aid not exceeding EUR 100000 over a continuous period of three years is not considered incompatible with the common market. The rule was introduced to reduce the cost of administrative burden on the Commission created by state aid control and to facilitate subsidies for small and medium enterprizes (SME), which are expected to use low amounts of $R \& R$ aid more often. The ceiling amount in the de minimis rule is a gross grant or its equivalent. The rule does not apply to transport, shipbuilding, agriculture, fisheries sectors, export-related activities, and aid promoting domestic over imported products. Other block exemptions concern training

\footnotetext{
8 ibidem.

${ }^{9}$ OJ L 10, 13.1.2001, p.30. In 2006 the Commission proposed to increase the ceiling of the de minimis rule to $200000 \mathrm{EUR}$, but the decision to adopt it was not yet made.
} 
aid, employment aid and aid for SMEs. The structure of state aid control is depicted in figure 1.

Figure 1: The Commission investigates aid's compatibility with the common market in cases left to its discretion.

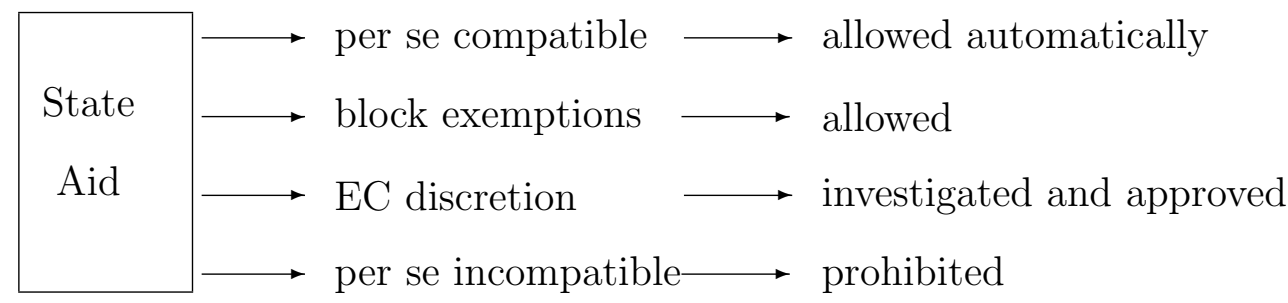

The Commission has worked out several documents defining the rules in the state aid control process, depending on the objective and the instrument of aid. So-called horizontal guidelines explain which aid can be approved depending on its objective: regional aid, aid for research and development (R\&D), environmental aid, aid for risk capital and aid for rescuing and restructuring $(\mathrm{R} \& \mathrm{R})$ firms in difficulty all have their guidelines published in the Official Journal of the European Union. Sectors like broadcasting, coal, shipbuilding, steel, electricity, postal services, synthetic fibres and motor vehicles also have their specific rules. Finally, regulations define how governments are allowed to use specific aid instruments (state guarantees, public land sales, export credit insurance and fiscal aid).

\subsection{Community Guidelines on State Aid for Rescuing and Re- structuring Firms in Difficulty}

At the Commission's discretion, rescue and restructuring aid for a firm in difficulty may be considered compatible with the common market based on Article 87 (3), points a) and c). Governments may support certain industries or sustain jobs in poor or dependent on one big firm regions in order to facilitate social and regional cohesion. Detailed rules, according to which the Commission decides on such cases, are specified in the Community Guidelines on State Aid for Rescuing and Restructuring Firms in Difficulty, ${ }^{10}$ described

\footnotetext{
${ }^{10}$ OJ C 244, 1.10.2004, p.2.
} 
in the remainder of this section.

The guidelines explain the way the European Commission exercises its discretion in the field of bailouts. The guidelines were adopted in 1994, amended in 1999 and 2004, and the current version - on which I focus here - stays in power until October 9, 2009. The general approach of the Commission to $\mathrm{R} \& \mathrm{R}$ aid is that it is the most problematic type of subsidies. R\&R aid is directed towards inefficient firms, so it is likely to act directly against competitive forces that drive the firm out of the market. According to the guidelines, $R \& R$ subsidies are justified only in three circumstances: by social or regional cohesion considerations, to support small and medium-sized enterprizes, and in presence of a menace of high market concentration. While the first objective is a matter of social judgement, the remaining two are economic issues.

A firm liable to $\mathrm{R} \& \mathrm{R}$ aid, called a firm in difficulty, is "unable, whether through its own resources or with the funds it is able to obtain from its owners/shareholders or creditors, to stem losses which, without outside intervention by the public authorities, will almost certainly condemn it to going out of business in the short or medium term." ${ }^{11}$ Such firms typically have "increasing losses, diminishing turnover, growing stock inventories, excess capacity, declining cash flow, mounting debt, rising interest charges and falling or nil net asset value." 12 This includes also firms that filed for insolvency, subsidiaries of firms that are also in difficulty, or subsidiaries, which prove that the state of difficulty is their own responsibility and the parent cannot help. Newly created firms (up to 3 years old) are not eligible for R\&R aid. The most important element of the definition is that without the subsidy the firm would exit the market - only a state intervention can keep it in operation.

Bailouts consist of two kinds of subsidies: rescue and restructuring. While a rescue subsidy keeps the firm in operation for the time needed to asses the situation and prepare a plan of further action, restructuring aid is a long-term assistance in the implementation of the restructuring plan, which must aim at restoring firm's viability. Each of rescue and restructuring subsidies can be granted only once every ten years (five in the agricultural

\footnotetext{
${ }^{11}$ ibidem, p.3.

12 ibidem.
} 
sector). This is the so-called one time - last time principle and refers to all types of beneficiaries: large firms, groups of firms, firms in assisted areas and SME's. If both aid types are granted, the order also matters: rescue aid should be given before restructuring aid, otherwise the restructuring process failed to restore viability and a firm is not eligible for the rescue subsidy. From the economic point of view, strict application of the one time - last time principle is crucial, since it reduces efficiency distortions caused by soft-budget constraints.

Rescue aid is granted as a loan or a loan guarantee at a market interest rate for a maximum of six months. After that time, a plan of restructuring or a liquidation plan must be presented to the Commission. In principle, there is a maximum amount of rescue aid, which depends on earnings before interest and taxes, depreciation and working capital according to a formula in the appendix to the guidelines, but exceptions are possible.

Restructuring subsidy is granted only to those firms that present a convincing plan of restoring the firm's long-term viability and a market survey. If the market power of the beneficiary is significant, the Commission imposes compensatory measures such as divestiture of assets or reduction in capacity. The beneficiary is expected to make a significant contribution to cover restructuring costs: $25 \%$ in case of a small firm, $40 \%$ for a medium-sized firm and 50\% for a large firm. The implementation of the restructuring plan should be communicated to the Commission by reports at least annually.

Aid for large firms must be notified individually each time, while for SMEs aid schemes are possible. SMEs (with the exception of the agricultural sector) and firms from assisted areas have less strict rules as far as compensatory measures and reporting are concerned. The guidelines do not apply to coal and steel sectors.

\subsection{Summary statistics}

In the time period from 1995 to 2003, the Commission made 86 decisions on granting individual R\&R subsidies to 79 firms from $10 \mathrm{EU}$ countries. The first statistical study of the decisions was done by Chindooroy et al. (2005). In this section, I revise summary statistics related to further questions addressed in this paper. A cross-sectional data set 
is used, with each decision as a unit observation. ${ }^{13}$

The decisions I analyze were made during the years 1995-2003. The starting year is 1995, which is the first year when decisions were based on the guidelines on $\mathrm{R} \& \mathrm{R}$ aid. In some cases, however, the subsidy was notified ex post, hence the year of granting aid was earlier than the decision itself. The last year is 2003, just before the EU enlargement and introduction of the new version of the guidelines. The most aid-intensive period was 1996-1998 with 13-15 subsidies granted each year. After 1998, the number of cases has halved and oscillated around 7 (see table 1).

Table 1: Year of granting R\&R subsidy.

\begin{tabular}{cccc}
\hline Subsidy year & Rescue cases & Restructuring cases & Total \\
\hline 1992 & 0 & 1 & 1 \\
1993 & 0 & 1 & 1 \\
1994 & 1 & 5 & 6 \\
1995 & 3 & 5 & 8 \\
1996 & 5 & 8 & 13 \\
1997 & 6 & 9 & 15 \\
1998 & 3 & 11 & 14 \\
1999 & 1 & 5 & 6 \\
2000 & 0 & 2 & 2 \\
2001 & 6 & 2 & 8 \\
2002 & 6 & 2 & 8 \\
2003 & 3 & 1 & 4 \\
\hline Total & 34 & 52 & 86 \\
\hline Populion: Cross & & &
\end{tabular}

Population: Cross-section of decisions.

There is a clear tendency of granting more rescue aid in recent years. Before 2001, the number of rescue cases was lower than restructuring aid cases. Starting with 2001, this tendency was reversed. The change in the pattern coincides with the Commission's increased political efforts to limit state aid. For example, the Lisbon Agenda in 2000 encouraged the EU governments to cut state aid for inefficient firms and redirect it to firms with potential for innovation and growth.

\footnotetext{
${ }^{13}$ For the description of the data set construction procedure, see the Appendix B.
} 


\section{Differences between rescues and restructures}

The nature of a rescue subsidy as defined by the guidelines is very different from restructuring aid. While the former can be granted to any firm with an acute problem as a short-term solution, restructuring aid is a long-term assistance with viability as an objective. Table 2 reveals that differences indeed exist. For each subsidy type, I report the total number of firms receiving such aid, followed by the number of state-owned and private firms, the number of bankrupt and surviving firms, the number of firms sold after the subsidy and average employment. State-ownership means that the state controls more than $50 \%$ of the firm's capital. Bankruptcy and sale are observed in the time period between the subsidy and 2003. Note that ownership status is known only for 69 firms and survival status only for 75 firms (bottom row of table 2).

Table 2: Differences between subsidy types.

\begin{tabular}{|c|c|c|c|c|c|c|c|}
\hline Subsidy type & Total & State-owned & Private & Bankrupt & Survived & Sold & $\begin{array}{l}\text { Avg. } \\
\text { empl }\end{array}$ \\
\hline Rescue & 27 & 5 & 19 & 13 & 13 & 4 & 3404 \\
\hline Double rescue & 1 & 1 & 0 & 1 & 0 & 0 & 1791 \\
\hline Restructure & 45 & 21 & 17 & 8 & 34 & 18 & 6333 \\
\hline Double restructure & 1 & 1 & 0 & 0 & 1 & 0 & 3508 \\
\hline Rescue and restructure & 5 & 2 & 3 & 0 & 5 & 1 & 8730 \\
\hline Total & 79 & 30 & 39 & 22 & 53 & 23 & 5340 \\
\hline
\end{tabular}

Population: Cross-section of firms.

The first observation is that there were many more restructuring aid than rescue aid cases. Seven firms received a double subsidy. Five of them were rescue cases followed by restructuring aid, which is the pattern promoted by the guidelines. In the other two cases, the one time -last time principle was clearly violated. Nearly a half of restructuring aid cases concerned state-owned firms, while less than one-fifth of rescue cases involved public firms. In addition, only state-owned firms benefited from the two cases breaking the one time -last time principle. The null hypothesis that ownership and the subsidy type are independent is rejected based on the Pearson's chi-squared test at $5 \%$ significance level. ${ }^{14}$

\footnotetext{
${ }^{14}$ This is only very weak evidence of the correlation, since I have few observations and Pearson's chisquared test uses a limit distribution.
} 
If one agrees that restructuring aid is more attractive to firms in difficulty than rescue aid, then the data suggest that state-owned firms had a favorable treatment.

Turning to the bankruptcy rate, 22 firms went bankrupt, which makes about $30 \%$ of all bailed-out firms. The distribution of bankruptcies is biased towards rescues: a half of all rescue aid cases ended up with a bankruptcy, compared with less than a quarter of restructuring aid cases. The null hypothesis that the type of subsidy is independent of bankruptcy is rejected based on the Pearson's test at $2 \%$ significance level. The bias towards rescues is natural given the characteristics of rescue aid, which is only temporary and is not meant to support a restructuring process. Restructuring aid, however, should never end up with bankruptcy -its aim is to get the firm back to viability. This aim was not achieved in 8 cases out of 45 total $(17.7 \%)$.

Regarding the distribution of firms that were sold to a new owner after receiving the subsidy, a higher proportion of restructured firms were sold than the proportion of rescued firms. This suggests that a restructuring subsidy can be used to increase the value of a firm in difficulty before sale, for example before privatization. Out of 28 state-owned firms, 13 were privatized after receiving a restructuring subsidy. In a few cases, privatization was even a condition for R\&R aid approval demanded by the Commission. All privatized firms survived.

Finally, looking at average employment, firms with restructuring aid had on average more employees than firms receiving rescue aid. This suggests a too-big-to-fail effect, meaning that bigger firms get more support from the state in case of distress, because their exit would potentially have a larger negative externality on the state-wide or regional economy.

\section{Bailout policies in European countries}

The EU member states use R\&R subsidies in a very differentiated way. Table 3 highlights the differences across countries in detail. For each country, I report the total number of subsidized firms, the number of rescue and restructuring subsidy types granted, the number of state-owned and private firms, the number of bankrupt and surviving firms, 
the number of firms sold after the subsidy, and finally, average employment in subsidized firms.

Table 3: Differences across countries.

\begin{tabular}{lr|rl|rl|rl|rr}
\hline Country & $\begin{array}{r}\text { Firms } \\
\text { No. }\end{array}$ & Restr. & Rescue & Public & Private & Bankrupt & Survived & Sold & Avg. empl. \\
\hline Greece & 1 & 1 & 0 & 1 & 0 & 0 & 1 & 0 & 7529 \\
Netherlands & 2 & 1 & 1 & 1 & 1 & 1 & 1 & 1 & 4906 \\
Austria & 4 & 3 & 3 & 1 & 3 & 1 & 3 & 1 & 390 \\
UK & 4 & 2 & 2 & 2 & 2 & 0 & 4 & 2 & 4640 \\
France & 11 & 9 & 3 & 9 & 2 & 0 & 11 & 6 & 19187 \\
Portugal & 4 & 4 & 1 & 1 & 1 & 0 & 3 & 1 & 141 \\
Spain & 10 & 8 & 2 & 5 & 5 & 4 & 6 & 2 & 928 \\
Italy & 15 & 10 & 6 & 6 & 5 & 6 & 7 & 5 & 5447 \\
Belgium & 4 & 2 & 2 & 1 & 0 & 1 & 2 & 0 & 3037 \\
Germany & 24 & 12 & 14 & 3 & 20 & 9 & 15 & 5 & 3774 \\
\hline Total & 79 & 52 & 34 & 30 & 39 & 22 & 53 & 23 & 5340 \\
\hline
\end{tabular}

Population: Cross-section of decisions.

Germany leads with 24 bailed-out firms, followed by Italy, France and Spain with 15, 11 and 10 firms respectively. Notably, there are also 5 member states that did not bailout any firm (not in the table): Denmark, Finland, Ireland, Luxemburg and Sweden. While in case of Luxemburg one can have doubts if this result is because of government's policy or economy size, in the other four cases it looks like a hard no-bailout policy.

A comparison of the policies of Germany and France provides interesting insights. Among 24 Germany's beneficiaries, the majority received rescue aid. Only 3 beneficiaries were state-owned and employment was lower than the total average. In contrast, France used mainly restructuring aid, mainly directed to state-owned firms and had the highest number of sold firms. French bailed-out firms employed four times more people than the total average and none of them went bankrupt. These two policies seem to be the opposites. Germany provides short-term support for smaller private firms, while France uses R\&R aid to restructure huge state-owned firms. Italy's and Spain's policy is similar to that of France, but the bankruptcy rates are higher.

Differences in countries' policy can also be found in the distribution of industries, from which the bailed out firms came (I use a 2-digit NACE codes as industry classification, see table 13 in the Appendix A). The distribution is presented in table 4. Some countries 
Table 4: Countries' bailouts per industry.

\begin{tabular}{lcccccccccr|r}
\hline \multicolumn{10}{c}{ Country } \\
\hline Industry & EL & NL & AT & UK & FR & PT & ES & IT & BE & DE & Total \\
\hline services &. &. &. &. & 2 &. &. & 2 & 1 & 1 & 6 \\
finance &. &. &. & 1 & 5 &. &. & 2 &. & 1 & 9 \\
transport & 1 &. &. & 2 & 3 &. &. & 1 & 2 & 2 & 11 \\
electric water &. &. &. & 1 &. &. &. &. &. &. & 1 \\
trade &. &. &. &. &. &. & 1 &. &. & 1 & 2 \\
construction &. &. & 1 &. &. & 1 & 1 & 6 &. & 2 & 11 \\
manufacturing &. & 2 & 3 &. & 1 & 3 & 7 & 3 & 1 & 17 & 37 \\
mining &. &. &. &. &. &. & 1 & 1 &. &. & 2 \\
\hline Total & 1 & 2 & 4 & 4 & 11 & 4 & 10 & 15 & 4 & 24 & 79 \\
\hline Population
\end{tabular}

Population: Cross-section of firms.

grant R\&R aid mainly in sectors, where negative externalities of a bankruptcy may be painful for the whole economy (e.g. UK). Other countries bail out in sectors, where such externalities are less likely to exist (Netherlands, Austria, Portugal, Spain). Finally, there are countries that grant R\&R aid economy-wide (Italy, Germany, France). The Pearson's test rejects the hypothesis that the industry and the country of $R \& R$ aid receivers are independent.

\section{Characteristics of bailed-out firms}

Table 5 presents summary statistics about $R \& R$ aid beneficiaries. Industries supported by $R \& R$ aid are state-wide infrastructure providers in transport, electricity/water supply and banking, but also manufacturing and construction sectors, trade, and services. A striking observation is that nearly half of all cases involved the manufacturing industry, a third of which went bankrupt after receiving the aid. A high share went also to the construction sector, where bankruptcies were more common: 6 out of 10 firms left the market. There were no bankruptcies in the financial, trade and electricity and water supply sectors. Regarding the ownership distribution, the share of state-owned firms is very large relative to the share of state-owned firms in the total EU economy, but the majority of beneficiaries are still private. State-owned firms tend to go bankrupt less often than private ones. All firms which were sold after the subsidy survived. 
Table 5: Time-invariant firm characteristics.

\begin{tabular}{lrr}
\hline & Total & Bankrupt \\
\hline Industry & & \\
services & 4 & 1 \\
finance & 9 & 0 \\
transport & 11 & 1 \\
electric \& water supply & 1 & 0 \\
trade & 2 & 0 \\
construction & 10 & 6 \\
manufacturing & 36 & 12 \\
mining & 2 & 2 \\
Total & 75 & 22 \\
\hline Ownership & & \\
private & 38 & 13 \\
state-owned & 30 & 7 \\
Total & 68 & 20 \\
\hline For sale & & \\
unchanged & 50 & 21 \\
new owner & 23 & 21 \\
Total & 73 &
\end{tabular}

Population: Cross-section of firms.

Table 6 reports summary statistics on age and employment. Age is defined as the

Table 6: Other firm characteristics.

\begin{tabular}{lrrrrr}
\hline Variable & Obs & Mean & $\begin{array}{r}\text { Std. } \\
\text { Dev. }\end{array}$ & Min & Max \\
\hline Age (years) & 66 & 58 & 69.3 & 1 & 457 \\
Average employment & 75 & 5340 & 11768 & 36 & 69671 \\
\hline
\end{tabular}

Population: Cross-section of firms.

number of years passed between incorporation and the subsidy. R\&R beneficiaries are 58 years old on average. There is one firm that was only 1 year old when it was subsidized, which is against the rules of the guidelines, since firms younger than 4 years cannot be bailed out. There is also one 457 years old firm. Average employment is the average number of people employed in the period between the bailout and the year $2003 .^{15}$ It reached 5340, indicating that bailed-out firms were on average large.

\footnotetext{
${ }^{15}$ I use average employment to proxy for the size of the firms. Due to numerous missing data for this variable, I cannot use employment in the subsidy year.
} 


\section{Summary}

The summary statistics highlight two typical problems with $R \& R$ aid: high mortality rate and a strong influence of political economy issues. Bankruptcy rate amounts to about $30 \%$ of all beneficiaries and $17 \%$ of restructuring aid beneficiaries. Such a high bankruptcy rate suggests possible shortcomings in the Commission's decision-making process, since bailouts of firms with bad prospects for survival should not have been approved. The political economy of R\&R aid involves at least three issues. State-owned firms are overrepresented and they get more restructuring aid than private firms. Governments' bailout policies are very heterogenous across countries and vary from a hard no-bailout approach to frequently given support to firms from various industries. Finally, several cases contradict the one time - last time principle, indicating that the guidelines were not the only criterion of the Commission when approving the subsidy.

I address these issues in the next sections. In section 3, I evaluate bailouts in terms of their effectiveness in preventing exit and in section 4, I analyze member states' bailout policies.

\section{Exit patterns for bailed-out firms}

The objective of a bailout is to prevent beneficiary's almost certain exit. Exit patterns are therefore an important information for the assessment of bailouts' effectiveness: exit implies that the bailout has failed. A concept designed to examine exit is a hazard rate, which relates the probability of exit in a given year to the time passed since the bailout and firms' characteristics. Assuming that $R \& R$ aid prevents exit, the hazard rate for bailedout firms should be low and decreasing in time. Another reason to estimate the hazard rate of $\mathrm{R} \& \mathrm{R}$ aid beneficiaries is to compare it to the existing hazard rate estimates for firms protected by Chapter 11 of the Bankruptcy Act in the US (Bandopadhyaya, 1994; Li, 1998). Both institutions aim at exit prevention, so a comparison of their effectiveness could provide interesting insights.

To the best of my knowledge, the hazard rate for $\mathrm{R} \& \mathrm{R}$ beneficiaries has never been 
estimated. The first empirical study on R\&R aid, Chindooroy et al. (2005), provides estimates for a time-invariant probability of survival. Their results show that rescue subsidy beneficiaries have a lower survival chance than firms getting a restructuring subsidy, and firms which got subsidies after the year 1999 had higher survival chances. As an estimation method they use a one-period discrete choice model. However, according to Shumway (2001) and the following literature, discrete choice models with cross-sectional data give biased and inconsistent estimates of the probability of survival. This is because one-period models do not take into account time changes in the proportion of surviving subjects: if a firm went bankrupt, it is denoted as bankrupt no matter how long it lived after the subsidy. Censored observations, on the other hand, meaning firms which survive until the end of the observation period, are counted as survivors for ever, although it cannot be excluded that they go bankrupt later. This is particularly important for my data, since I have a significant number of censored observations.

The drawbacks of discrete choice models are resolved by the hazard rate approach. Hazard rate is defined as instantaneous probability of an event (e.g. bankruptcy) at a time point. The main characteristic of hazard models is that they define event's risk at each point in time. This allows to code bankrupt and censored firms correctly as active or not at a certain point in time. In addition, time-varying variables and hence more information can be utilized.

Two estimation methods will be applied: a non-parametric and a parametric one. In the estimation I use an unbalanced panel data set. ${ }^{16}$ I examine 75 R\&R aid beneficiaries for which the surviving status in the year 2003 in known. The time unit is a calendar year. It starts being counted from the year when the subsidy was given and it stops in the year of bankruptcy or in 2003, if the firm survived until then (these are the censored observations, which receive a special treatment in the methodology I will use). Descriptive statistics of survival data are reported in table 7. Roughly one fourth of all observations comes from bankrupt firms. Average survival time for bankrupt firms is shorter than for censored firms by 1.8 years.

\footnotetext{
${ }^{16}$ For details, see the Appendix B.
} 
Table 7: Description of survival data.

\begin{tabular}{lr}
\hline No. of observations & \\
Total & 409 \\
Bankrupt & 92 \\
Censored & 317 \\
\hline Average survival (years) & \\
Total & 5.45 \\
Bankrupt & 4.18 \\
Censored & 5.98 \\
\hline Population: Panel.
\end{tabular}

\subsection{Non-parametric estimation of exit patterns}

Non-parametric estimates of the hazard rate are also called life-tables, as they were invented to analyze the life length for the population in the United Kingdom and became later the cornerstone of modern demography. ${ }^{17}$

The data is arranged in the following way: the calendar year when the subsidy was granted is counted as year number 1, the following year gets the number 2 and so on, until the bankruptcy or 2003, the last year of the observation period. For each year $j$, the number of firms entering this year is calculated $\left(N_{j}\right)$, the number of firms bankrupt in that year $\left(b_{j}\right)$, the number of surviving firms for which $j$ is the last year of observation (censored, $\left.c_{j}\right){ }^{18}$

The discrete hazard rate in year $j$ is the probability of going bankrupt during the year $j$, conditional on surviving until the beginning of that year. The estimate is simply

$$
h_{j}=\frac{b_{j}}{N_{j}}
$$

that is the number of aid beneficiaries going bankrupt in year $j$ divided by the number of surviving until year $j$. The standard error:

$$
s_{h_{j}}=\frac{h_{j}}{\sqrt{b_{j}}} .
$$

\footnotetext{
${ }^{17}$ John Graunt, "Natural and Political Observations Made upon the Bills of Mortality", London, 1662.

${ }^{18}$ All censored firms are observed until the end of the year, so actuarial adjustment is not used. Estimations are done with STATA 9.
} 
For the years, when the number of bankruptcies is zero, standard errors cannot be calculated. The results are presented in table 8. The first row can be read as follows: during

Table 8: Life-table estimates.

\begin{tabular}{lccccc}
\hline Year & Beg. Total & Bankruptcies & Lost & Hazard & St. Error \\
$j$ & $N_{j}$ & $b_{j}$ & $c_{j}$ & $h_{j}$ & $s_{h_{j}}$ \\
\hline 1 & 75 & 4 & 4 & 0.0533 & 0.0267 \\
2 & 67 & 2 & 5 & 0.0299 & 0.0211 \\
3 & 60 & 4 & 6 & 0.0667 & 0.0333 \\
4 & 50 & 6 & 1 & 0.1200 & 0.0490 \\
5 & 43 & 1 & 3 & 0.0233 & 0.0233 \\
6 & 39 & 0 & 8 & 0.0000 &. \\
7 & 31 & 1 & 9 & 0.0323 & 0.0323 \\
8 & 21 & 2 & 7 & 0.0952 & 0.0673 \\
9 & 12 & 0 & 4 & 0.0000 &. \\
10 & 8 & 2 & 4 & 0.2500 & 0.1767 \\
11 & 2 & 0 & 1 & 0.0000 &. \\
12 & 1 & 0 & 1 & 0.0000 &. \\
\hline
\end{tabular}

Population: Panel.

the year when they received the subsidy, 4 firms out of 75 went bankrupt. Another 4 firms went out of the sample, which means that they were subsidized in 2003 and survived that year. The probability of going bankrupt in the first year after the subsidy is 0.0533 with the standard error of 0.0267 .

The highest number of bankruptcies took place in the fourth year after the subsidy and it remained low after that (column 3). This suggests that the first four years are crucial in making a successful bailout. The last bankruptcies occur 10 years after the subsidy. The lost cases (column 4) are the censored observations ending in a given period. For example, in the seventh year the number of lost cases reaches nine, meaning that nine firms that were subsidized seven years before 2003 survived. Standard errors increase with time (column 6), since the sample gets smaller and smaller. After the eighth year, the number of observations drops below 20. In the tenth year two bankruptcies take place, but they are given too much weight due to the low sample size. For this reason, I only consider estimates until the eighth year.

The estimate of the hazard function is depicted in figure 2. The shape of the empirical hazard function shows the exit patterns of the $R \& R$ aid beneficiaries. During the first 
Figure 2: Empirical hazard function.

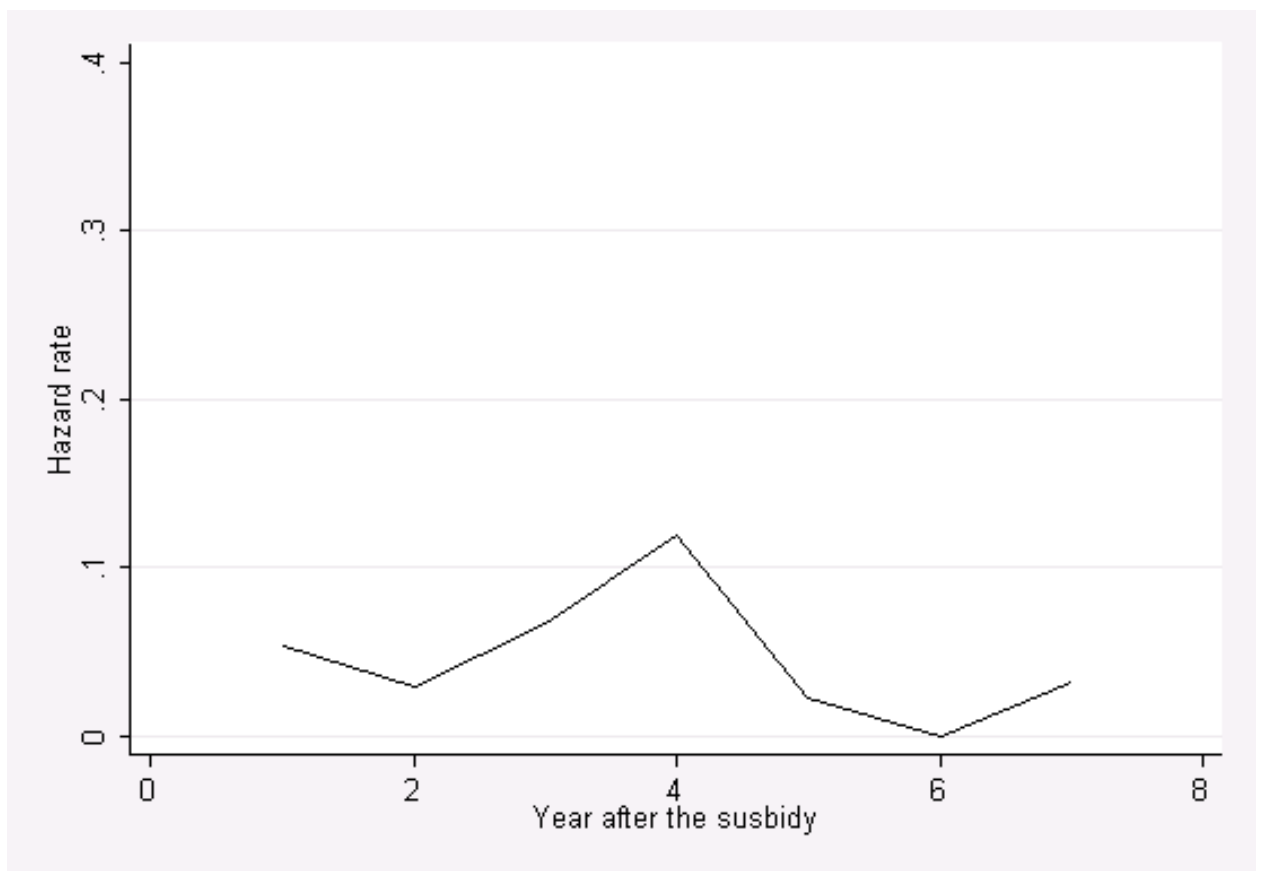

year the hazard decreases a little, reflecting the fact that some firms decide to liquidate immediately. Then the hazard increases and reaches the peak of $12 \%$ in the fourth year, meaning that during the first four years more and more firms exit. Only after the fourth year, the hazard drops to low levels.

Such a pattern suggests that $R \& R$ aid delays exit. Without the bailout firms would exit in the first year, but thanks to the subsidy they live for up to four years longer and exit later. The scale of this phenomenon is not negligible: 16 out of 75 firms went bankrupt within four years after receiving an R\&R subsidy.

\subsection{Parametric hazard rate estimation}

More detailed insights and predictions are possible with the parametric estimation of the hazard rate, however at the expense of functional and parametric assumptions.

\section{Methodology}

The data is discrete in time: instead of precise dates, only the years of subsidies and the bankruptcies are registered. In theory, however, firms may go bankrupt on any working 
day of the year, so the underlying true hazard is continuous. Such data needs a special model, which takes their nature into account. Denote the probability that a firm survives until the end of year $j$ by $S\left(j, X_{j}\right)$, where $X_{j}$ is a vector of firm's characteristics in year $j$. Denote the true continuous hazard rate for a firm with characteristics $X_{t}$ by $\theta\left(t, X_{t}\right)$ and the the end of year $j$ by $j_{1}$. The survivor function $S\left(j, X_{j}\right)$ can then be expressed as ${ }^{19}$

$$
S\left(j, X_{j}\right)=\exp \left(-\int_{0}^{j_{1}} \theta(u, X) d u\right)
$$

Now I assume that the continuous hazard rate satisfies the proportionality assumption

$$
\theta(t, X)=\theta_{0}(t) \exp \left(\beta^{T} X\right)
$$

This assumption means that firms with different values of the product $\beta^{T} X_{j}$ have proportional hazard rates, because the time-dependent part $\theta_{0}$ (called the baseline hazard) is common for all firms. Substituting (4) into (3), the final formula for the survival probability is

$$
S\left(j, X_{j}\right)=\exp \left(-H(j) \exp \left(\beta^{\prime} X_{j}\right)\right)
$$

with $H_{j}=\int_{0}^{j_{1}} \theta_{0}(u) d u$.

The discrete hazard rate is the probability of exit during the year $j$, conditional on surviving until year $j$, which can be written down as

$$
h\left(j, X_{j}\right)=\frac{S\left(j, X_{j}\right)-S\left(j-1, X_{j}\right)}{S\left(j-1, X_{j}\right)}=1-\frac{S\left(j, X_{j}\right)}{S\left(j-1, X_{j}\right)}
$$

Substituting the expression for the continuous survival probability (5) into the discrete hazard rate (6) and manipulating the formula I get the equation to estimate:

$$
h\left(j, X_{j}\right)=1-\exp \left[-\exp \left(\beta^{\prime} X_{j}+\gamma_{j}\right)\right]
$$

\footnotetext{
${ }^{19}$ For the details on the basic relationships between survival and hazard functions, see the Appendix C or Jenkins (2004).
} 
which describes the probability of bankruptcy in period $j$ as a complementary log-logistic function (or cloglog) of the firm-specific vector $X_{j}$ and a function of time $\gamma_{j}=\log (H(j)-$ $H(j-1))$. Note that the two variables are additively separated, which makes the equation easy to estimate. In statistics, cloglog function is defined as $g(x)=1-\exp [-\exp (x)]$ and it is a discrete analog of the log-logistic hazard function. It is particularly suitable for data with few nonzero outcomes due to the asymmetry of its tails: the right tail converges to one more quickly than the left tail converges to zero, so that the positive values are given more weight (Buckley and Westerland, 2004).

\section{Implementation}

To estimate the equation (7), variables representing $h\left(j, X_{j}\right), X_{j}$ and $\gamma_{j}$ are needed. I choose them in the following way. The dependent variable is an indicator of the bankruptcy of firm $i$ in year $j$ :

$$
\mathrm{BANKR}_{i j}= \begin{cases}1 & \text { if firm } i \text { went bankrupt in year } j \\ 0 & \text { otherwise. }\end{cases}
$$

As the subject characteristics $X_{j}$, subsidy type, firm's age since incorporation, state ownership, employment and industry are considered.

Subsidy type is included to estimate the difference in effectiveness between rescue and restructuring aid. It is a dummy variable

$$
\mathrm{TYPE}_{i}= \begin{cases}0 & \text { if firm } i \text { got only a rescue subsidy } \\ 1 & \text { if firm } i \text { got a restructuring subsidy }\end{cases}
$$

According to this definition, TYPE equals one also in all cases, where both a rescue and a restructuring subsidy and in the case of two restructuring subsidies granted to one firm. I expect the coefficient to be negative, since restructuring aid should ensure lower bankruptcy probability of the beneficiary than rescue aid. Potentially, this variable might be endogenous. The subsidy type, which is chosen by the government, could be correlated 
with the error term from the equation. For example, a firm which is a monopolist (like a state-wide railway) has a very strong bargaining power, which can have influence on both the subsidy type and the hazard. But in my data set I do not have information on the bargaining power of aid receivers, so this correlation is captured by the error term and creates an endogeneity problem. As a consequence, the estimates might be biased. I deal with this problem explicitly by modelling the government's choice and applying a simultaneous estimation in section 4 , but for now it remains a problem to keep in mind when interpreting the hazard estimates.

Variable LNAGE is the natural logarithm of years from incorporation to the subsidy year. I expect the coefficient of this variable to be negative, reflecting the fact that a longer market presence gives know-how which decreases the bankruptcy probability.

A variable of particular interest is firm's ownership $\mathrm{PUBLIC}_{i}$, equal to one if the state has a majority stake in firm $i$. If public firms are less efficient than private firms, the estimated coefficient of this variable should be positive. On the other hand, if public ownership is of an advantage in financial distress due to lobbying or high bargaining power, the coefficient will be negative.

The size of a firm is represented by a logarithm of its average employment. I expect the coefficients to be negative - if bailouts prevent job cuts, they should work out especially in case of big firms. In a few specifications, public employment is separated from private employment by using two variables: SIZEPUBLIC $_{i}$ and SIZEPRIVATE $_{i}$. Since the data on employment has many missing points, the average number from all available during the years 1992-2003 is used and is constant over in the panel.

Bankruptcy literature suggests that sector characteristics are significant determinants of survival (e.g. Shumway (2001)). Business cycles also differ across sectors. I therefore add dummies for industries, in which firms were active: INFRASTR for electricity, transportation and financial services, SERVICE for services and trade and MINMAN for mining and manufacturing. Construction sector is left out as a reference category.

Finally, a function of time needs to be estimated $\left(\gamma_{j}\right.$ from equation $\left.(7)\right)$ to capture duration dependence. Since the empirical hazard rate as depicted in figure 2 does not 
have any typical shape, I choose to specify the baseline hazard in a non-parametric way: I create dummies for each survived after the subsidy year. There are four years, in which no bankruptcies were observed $(6,9,11$ and 12), and for these years the hazard cannot be calculated. As survival literature recommends, I drop observations from these years and the total number of observations decreases to 355 . When predicting the hazard for those years, I assume that it is the same as in the preceding year.

The equation to estimate is thus:

$$
\begin{aligned}
P\left(\text { BANKR }_{i j}=1\right) & =g\left(\beta_{1} \text { TYPE }_{i}+\beta_{2} \text { LNAGE }_{i j}+\beta_{3} \text { PUBLIC }_{i}+\right. \\
& +\beta_{4} \text { SIZEPUBLIC }_{i}+\beta_{5} \text { SIZEPRIVATE }_{i}+\beta_{6} \text { INFRASTR }_{i} \\
& \left.+\beta_{7} \text { SERVICE }_{i}+\beta_{8} \text { MINMAN }_{i}+\sum_{j=1}^{j=8} \beta_{9 j} \gamma_{j}\right)
\end{aligned}
$$

where $g(x)=1-\exp [-\exp (x)]$ is the complementary log-logistic function, $j$ is a year index and $i$ is a firm index. I estimate three models with different variable sets, since for a few firms data on PUBLIC, LNAGE and employment is missing and adding these variables to the regression reduces the number of observations. In the third model, which includes public ownership, infrastructure dummy is dropped, because in the reduced panel it becomes a perfect predictor for survival. Standard errors were adjusted for within-firms correlation. Marginal effects were calculated for the average value of each variable.

The estimation method is conditional maximum likelihood. Apart from its doubtless advantages like consistency and asymptotic efficiency, it allows to account for censoring very easily. Suppose a subject $i$ went bankrupt in year $j$ and $T(j)$ is a bankruptcy indicator for period $j$. The likelihood contribution of such a (non-censored) observation $i$ is $P\left(T_{i}=j\right)$. For a censored observation $i$ that survives beyond the last time period $j$, the likelihood contribution simply is $P\left(T_{i}>j\right)=S_{i}\left(j, X_{i}\right)$. In this way, information from the censored observations can be correctly extracted in the estimation.

\section{Results}

Marginal effects are presented in table 9. The first part of the table shows the effects 
Table 9: Estimates of the marginal effects on the hazard rate.

Dependent variable: bankruptcy

\begin{tabular}{|c|c|c|c|}
\hline Variable & Model 1 & Model 2 & Model 3 \\
\hline \multicolumn{4}{|c|}{ Subsidy and firm characteristics } \\
\hline Subsidy type & $\begin{array}{l}-0.100^{* *} \\
(0.028)\end{array}$ & $\begin{array}{l}-0.099^{* *} \\
(0.033)\end{array}$ & $\begin{array}{l}-0.096^{* * *} \\
(0.007)\end{array}$ \\
\hline Inage & & $\begin{array}{r}-0.000 \\
(0.935)\end{array}$ & $\begin{array}{r}0.002 \\
(0.747)\end{array}$ \\
\hline public & & & $\begin{array}{r}0.141 \\
(0.519)\end{array}$ \\
\hline sizepublic & & & $\begin{array}{r}-0.006 \\
(0.537)\end{array}$ \\
\hline sizeprivate & & & $\begin{array}{r}0.011 \\
(0.263)\end{array}$ \\
\hline infrastr & $\begin{array}{l}-0.044^{* * *} \\
(0.005)\end{array}$ & $\begin{array}{l}-0.040^{* *} \\
(0.019)\end{array}$ & \\
\hline service & $\begin{array}{r}-0.018 \\
(0.110)\end{array}$ & $\begin{array}{r}-0.012 \\
(0.389)\end{array}$ & $\begin{array}{r}0.042 \\
(0.467)\end{array}$ \\
\hline minman & $\begin{array}{r}-0.013 \\
(0.344)\end{array}$ & $\begin{array}{r}-0.008 \\
(0.590)\end{array}$ & $\begin{array}{r}0.021 \\
(0.253)\end{array}$ \\
\hline \multicolumn{4}{|c|}{ Baseline hazard dummies } \\
\hline$\gamma_{1}$ & $\begin{array}{l}-0.026^{* *} \\
(0.015)\end{array}$ & $\begin{array}{l}-0.031^{* *} \\
(0.029)\end{array}$ & $\begin{array}{l}-0.092^{* *} \\
(0.046)\end{array}$ \\
\hline$\gamma_{2}$ & $\begin{array}{l}-0.032^{* *} \\
(0.017)\end{array}$ & $\begin{array}{c}-0.033^{*} \\
(0.060)\end{array}$ & $\begin{array}{c}-0.081^{*} \\
(0.055)\end{array}$ \\
\hline$\gamma_{3}$ & $\begin{array}{r}-0.018 \\
(0.103)\end{array}$ & $\begin{array}{r}-0.024 \\
(0.128)\end{array}$ & $\begin{array}{l}-0.065^{* *} \\
(0.048)\end{array}$ \\
\hline$\gamma_{4}$ & $\begin{array}{r}-0.004 \\
(0.792)\end{array}$ & $\begin{array}{r}-0.010 \\
(0.569)\end{array}$ & $\begin{array}{l}-0.050^{* *} \\
(0.025)\end{array}$ \\
\hline$\gamma_{5}$ & $\begin{array}{l}-0.027^{* *} \\
(0.034)\end{array}$ & $\begin{array}{c}-0.029^{*} \\
(0.068)\end{array}$ & $\begin{array}{l}-0.056^{* *} \\
(0.012)\end{array}$ \\
\hline$\gamma_{7}$ & $\begin{array}{l}-0.024^{* *} \\
(0.023)\end{array}$ & $\begin{array}{l}-0.025^{* *} \\
(0.036)\end{array}$ & $\begin{array}{l}-0.047^{* * *} \\
(0.003)\end{array}$ \\
\hline$\gamma_{8}$ & $\begin{array}{r}-0.007 \\
(0.546)\end{array}$ & $\begin{array}{r}-0.010 \\
(0.531)\end{array}$ & $\begin{array}{l}-0.038^{* * *} \\
(0.004)\end{array}$ \\
\hline$\gamma_{10}$ & $\begin{array}{r}0.057 \\
(0.347)\end{array}$ & $\begin{array}{r}0.043 \\
(0.456)\end{array}$ & $\begin{array}{l}-0.030^{* * *} \\
(0.007)\end{array}$ \\
\hline $\mathrm{N}$ & 355 & 321 & 297 \\
\hline Nonzero outcomes & 22 & 19 & 18 \\
\hline chi2 & 163.613 & 142.823 & 157.450 \\
\hline $\mathrm{p}$ & 0.000 & 0.000 & 0.000 \\
\hline
\end{tabular}

Population: Panel. P-values in parenthesis.

$* * *(* *, *)$ denotes significance with $1 \%(5 \%, 10 \%)$ level in a two-tailed Wald test. 
of firm characteristics on the hazard in every year after the subsidy. As expected, the marginal effect for TYPE is significant and negative. Ceteris paribus, firms receiving a restructuring subsidy face the probability of bankruptcy about $10 \%$ lower than firms with only rescue aid. Restructuring aid is indeed more effective in preventing exit of firms in trouble. Several reasons may be responsible for this finding. Restructuring aid provides firms with more public funds, it assists them for a longer time-period, and it forces firms to introduce restructuring measures aimed at recovering vitality. The result is consistent with the estimate of Chindooroy et al. (2005), who find that firms with rescue aid have lower survival probability than restructuring aid receivers. Still, the effect might be biased due to the potential endogeneity. If firms receiving restructuring aid are different than firms receiving rescue aid, the difference in the hazard might be driven by firm types rather than aid types. This issue will be addressed in section 4 .

Another significant marginal effect exists for firms from the infrastructure sectors (transportation, electricity production and distribution, financial services), which have a lower hazard rate than the reference group - the construction sector. Holding everything else constant, these firms went bankrupt by $4 \%$ less often. The most likely reason for this result is that a bankruptcy of a firm from infrastructure sectors creates a negative externality on the whole economy. Suppose a large bank goes bankrupt. Households, businesses and governments lose their deposits, payments are disrupt, other banks working with the bankrupt bank get in trouble. As a consequence, not only the bank but also a large portion of the economic activity in the country is affected. Similar situations are likely to take place if a state-wide railway tracks operator or electricity distributor exits. The government may then find it optimal to bail out such firms to avoid the externality of the bankruptcy on the rest of the economy. This phenomenon is known as the "too big to fail" doctrine (Hughes and Mester, 1993; Kaufman, 2003).

The other firm-specific variables have no impact on the hazard. Marginal effects for LNAGE are close to zero and highly insignificant. This is in line with the results in the bankruptcy prediction literature (Shumway, 2001). Public ownership has a positive but insignificant marginal effect. Employment does not matter as well, in line with the 
estimates of Chindooroy et al. (2005).

The second part of table 9 presents results on the duration dependence. A dummy $\gamma_{j}$ picks up the impact of the $j$ th year after the subsidy on the hazard. In the third specification all marginal effects are significant, in the first two specifications four out of ten. For their interpretation, differences in their absolute values matter. A plot of the hazard rates predicted from the model 1 for firms in the manufacturing sector which received rescue or restructure subsidy is presented in figure 3. The predicted hazard has

Figure 3: Predicted hazard functions for the first 7 years.

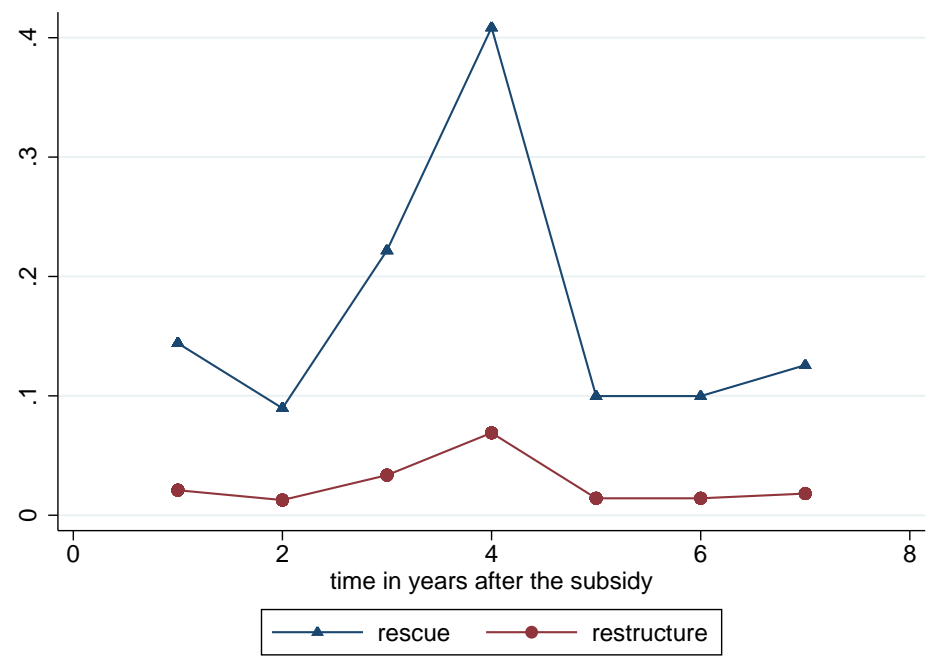

a small drop after the first year (not present in model 3), indicating that there are some firms, which exit immediately after receiving the subsidy. These firms do not even try to restructure and thereby do not live on the means provided by the subsidy. From the second to the fourth year the hazard is increasing: more and more firms exit. In the fourth year rescue aid beneficiaries exit at a high $40 \%$ rate. After the fourth year, the hazard drops and stays at a lower level. The pattern is the same as in the non-parametric model and suggests exit delay (called also "cash-and-carry" effect): firms cash the subsidy and enjoy it for some years before they eventually exit. The reason for exit can be twofold: either the firms do not want to restructure or they are not able to do it. In both cases, however, the subsidy failed to achieve its objective. 


\section{Robustness}

The results on duration dependence are consistent with the non-parametric hazard estimates. To check consistency with the results of Chindooroy et al. (2005), I estimate a simple probit with one observation per subsidized firm. The dependent variable is a dummy equal to one for bankrupt firms and zero for surviving firms. Instead of the baseline hazard dummies, I use a dummy RECENT equal to one for subsidies after 2000. The two main findings of Chindooroy et al. (2005) can be replicated also in my data set. Firms with rescue aid have lower survival chances than those with restructuring aid and firms subsidized after the year 2000 have a higher survival probability.

The firms receiving a double subsidy are not a regular case in the data set (only 7 firms). Still, dropping all observations for these firms and estimating all three models did not change the estimates dramatically. The only important difference is that industry dummies become significant at $10 \%$ level in the specification 1.

\subsection{Policy implications}

\section{Comparison with Chapter 11 protection}

The objective of $R \& R$ aid is to give a chance for restructuring and avoiding liquidation to firms which otherwise almost certainly exit. The same objective is given to the socalled Chapter 11 protection by the Bankruptcy Act in the United States, passed in 1978. However, Chapter 11 involves no transfers from the state budget. Instead, it provides businesses in distress with protection against their creditors. The negotiations between the firm in trouble and its creditors take place in a bankruptcy court. As a result, the debt is often reduced and some of the firm's assets are transferred to the creditors. According to the statistics by Couwenberg (2001), during the years 1980-1996 41\% of firms protected by Chapter 11 were successfully reorganized.

Duration of Chapter 11 protection was investigated in several studies. The analyzed spell is the time between filing for protection and the exit from Chapter 11 protection, which means return to vitality in nearly all cases (Li, 1998). Li (1999) applies a log-logistic 
hazard model with Bayesian analysis on a sample of 83 firms filing for protection in the years 1980-1994, 79 of which exit the protection before August 1994. His results show that bigger firms, with lower firm value, and running legal disputes stay longer under Chapter 11 protection. His estimated hazard function has an inverted U-shape, it grows during the first 21 months and then decreases to zero. Bandopadhyaya (1994) in contrast uses the Weibull distribution specification with the sample of 74 firms in trouble from the years 1979-1990, 43 of which emerged after Chapter 11 protection as a viable business. The results suggest that the higher outstanding interest in the firm and the higher capacity utilization in the industry, the shorter time spent under Chapter 11 protection. The estimated probability of leaving Chapter 11 as a vital business increases with time.

For R\&R subsidies the result is opposite: exit probability increases in the first four years. Compared with Chapter 11, R\&R aid is therefore less effective in achieving its objective. The most likely reason for this difference is the difference in the incentives that the two programs create. Chapter 11 protection is costly to the firm in trouble by the cost of legal services, by the cost of lost clients and contracts that look for a more stable business partner and by the lost equity which creditors get in return for cancelling some unpaid credits. Therefore, firms have incentives to quickly drop out of the protection program. In contrast, it is not costly for firms in trouble to take part in a state subsidy program. The aid beneficiaries get the aid and do not give any equity away. In this way, incentives to apply for aid are created also for those firms, which could survive without it, or those, which have no chance to survive in the long term.

The way out of this problem could be to introduce some features of Chapter 11 protection to R\&R aid. A suggestion along these lines was made by Nitsche and Heidhues (2006), who recommend the Commission to link R\&R aid to bankruptcy proceedings. Their main concern is exactly the distortion of the dynamic incentives caused by aid and the fact that aid mainly supports creditors and current, trouble-making managers of firms in distress. Opening a formal bankruptcy proceeding is usually a strong signal that the firm's managers have failed. If it was required for the $R \& R$ aid beneficiaries to file for bankruptcy, it could potentially harden the soft-budget constraints problem, because the 
managers will have stronger incentives to restructure the firm earlier. Such a solution is relatively easy to introduce.

A related problem is that European bankruptcy law is not uniform across member states. The general approach, however, is similar. Creditreform (2002) write: "One problem that all national laws have in common is that they offer too little protection from creditors for the companies concerned, thus hampering the chances of successful restructuring and rescue concepts. More effort is put into finding a culprit than into getting a viable company back on its feet." This opinion is confirmed in the data. Couwenberg (2001) calculated the ratios of the number of firms with restructuring plans confirmed by the bankruptcy courts to the total number of bankrupt firms for four countries in the 1990s. The ratio is the highest for the U.S. (11.48\%), much lower for France (2.6\%) and the U.K. (2.1\%) and the lowest for Germany (0.128\%\%). European firms in distress have a choice between very tough bankruptcy rules which rather take the side of the creditor and state subsidies which provide them with cost-free support. In this situation, it is clear that the number of bailouts in Europe is higher than the number of bailouts in the U.S. Better bankruptcy law in Europe, which would provide more effective reorganization procedures, could reduce the need to grant $\mathrm{R} \& \mathrm{R}$ aid.

A source of bias here might be sample selection problems, which I do not control for due to unavailability of the data. I have information on all R\&R aid cases, while the two cited Chapter 11 studies take only major bankruptcies into account, leaving many small bankruptcies out of the sample. ${ }^{20}$ On the other hand, the $R \& R$ aid cases are not the minor cases, since they do not fall under the de minimis rule, so the firm sets are to a large degree comparable.

\section{European bailout control}

European bailout control has been a subject of intense debate in the last years. In 2004 the guidelines were revised in order to introduce a somewhat stricter approach: the maximal amount and the time limit for rescue aid were defined, compulsory shares of firm's

\footnotetext{
${ }^{20}$ During the years 2001-2004, the average number of filings for Chapter 11 protection in the US reached 10675 (from 3.12.2004 News Release, Administrative Office of the U.S. Courts).
} 
contributions to the restructuring costs introduced, etc. ${ }^{21}$ By 2009, the next revision of the guidelines is planned. Assessment of bailouts control is also a part of the State Aid Action Plan announced by the Commissioner Neelie Kroes. ${ }^{22}$ For this discussion, a better understanding of weaknesses in the past European bailout control is crucial. The hazard model estimated in this section can be used for this purpose.

All bailouts in the data set were granted by the European governments and accepted by the Commission as compatible with the common market. A compatible bailout should have high chances for survival. Therefore, the Commission's performance can be assessed by counting how many times the Commission approved a bailout which had low probability of survival. This is the so-called type II error in the decision process: a failure to prohibit a non-compatible aid. ${ }^{23}$ Using the probability predictions from the hazard rate model, I show that if the Commission were tougher in the aid control process and prohibited aid more often, a number of bailout failures could be avoided.

Since the first four years show the highest mortality, it makes sense to measure success or failure of a bailout by the probability of surviving at least the first four years. I predict this probability for every firm in the data set (specification 1 from table 9 is used) and count the number of firms for which the predicted probability is lower than a given threshold. Out of these firms, I count the number of firms, which went bankrupt ex post. Table 10 presents the results.

Table 10: European bailout control.

\begin{tabular}{c|cc}
\hline Policy goal & Approved bailouts missing the goal & \\
\hline prob. of surviving $>4$ & Total & Failed ex post \\
\hline $90 \%$ & 43 & 13 \\
$80 \%$ & 17 & 9 \\
$70 \%$ & 8 & 6 \\
$50 \%$ & 7 & 5 \\
\hline
\end{tabular}

\footnotetext{
${ }^{21}$ See Nicolaides and Kekelekis (2005) for a detailed overview of the changes.

${ }^{22}$ Reforming Europes State Aid Regime: An Action Plan for Change, speech by Neelie Kroes, who is a Member of the European Commission in charge of Competition Policy, during the Wilmer Cutler Pickering Hale and Dorr and the University of Leiden joint conference on European State Aid Reform. Brussels, 14th June 2005.

${ }^{23}$ Prohibition of compatible aid (type I error) does not exist in my data set, since the Commission usually does not prohibit notified aid cases.
} 
The policy goal is the required minimal probability of survival for at least 4 years. Using the most loose policy goal of $50 \%$ gives 7 (from the total 86) subsidy approvals, which should not have been granted. In that case, 5 ex post bankrupt beneficiaries would not have been supported, although the remaining two ex post survivors would not have been subsidized as well. In the case of the most strict approach requiring $90 \%$ survival probability, every second bailout should not have been approved. That would allow to avoid 13 subsidies to firms exiting later. The best policy goal seems to be $70 \%$ : prohibition of these 8 bailouts would allow to avoid subsidizing 6 ex post bankrupt firms, leaving at the same time 2 ex post surviving firms without help.

To sum up, the decision-making process in the European bailout control shows significant shortcomings. Its effectiveness in terms of helping the firms in trouble to survive could be improved by eliminating cases with too low survival probability. In the assessment of this probability, firms should be required to survive at least four years. My estimates suggest that the most likely to go bankrupt are beneficiaries of rescue aid from sectors other than infrastructure providers (transportation, banking, electricity and water distribution).

\section{Industrial policy: how governments bail out}

One of the results so far is that the subsidy type is an important bankruptcy determinant. Firms receiving rescue aid have lower survival chances than firms with restructuring aid. It is, however, not clear whether this effect is due to better effectiveness of restructuring aid vs. rescue aid or due to the fact that restructuring aid was given to firms in a better shape. This problem will be addressed in this section. First, the determinants of governments' decisions to grant rescue vs. restructuring subsidy are identified. Having done this, the unbiased effect of the restructuring aid type on the hazard is estimated. 


\subsection{Industrial policy}

When governments decide to bail out a firm in difficulty, they choose one of the two types of $R \& R$ subsidies: rescue aid, which is limited in time, amount and form, and restructuring aid, which is long-term, can be granted in any form and is high enough to facilitate the restructuring process. Therefore, a firm receiving restructuring aid gets substantially more support from the state than a firm receiving only rescue aid.

The choice of the subsidy type is an outcome of the government's bailout policy. I identify determinants of this policy by estimating a discrete choice model with the dependent variable $\mathrm{TYPE}_{i}$ as defined by (9). When $\mathrm{TYPE}_{i}$ equals zero, the government gives firm $i$ a rescue subsidy for six months. During this time the firm decides about its future: liquidates or plans restructuring. When $\mathrm{TYPE}_{i}$ equals one, the government engages in the firm much more by participating in the cost of the restructuring process. This choice reveals government's industrial policy preferences: certain firms get more public funds than other firms.

I estimate a probit model

$$
\operatorname{Pr}\left(\mathrm{TYPE}_{i}=1\right)=\Phi\left(\beta^{\prime} X_{i}\right)
$$

where $i=1, \ldots, 79$ is a firm index, $\Phi$ is a c.d.f. of a standard normal distribution and $X$ is a vector of exogenous explanatory variables. Several explanatory variables are considered, each representing a theoretical argument for a particular government's choice.

The literature on soft-budget constraints suggests that state-owned firms get more state support than private firms. The reason for this is the lack of separation between ownership and control rights (Lin et al., 1998). An owner and creditor in one body has not enough commitment to provide sufficient incentives for managers. Another argument is related to the fact that state-owned firms often provide social goods in addition to goods they produce (e.g. kindergartens, pensions, housing, medical benefits). Costs of social good production are covered directly by the state. Röller and Zhang (2005) show that firms have incentives to become less efficient in the private good market in order to 
extract more money from the state. Public firms are also likely to be more efficient in lobbying the government than private firms. To measure the impact of public ownership on governments' bailout decisions, I add the dummy variable $\mathrm{PUBLIC}_{i}$ to the regression (11). The coefficient is expected to be positive.

The number of employees in the firm in trouble should also matter for a government considering a bailout. A bankruptcy of a big firm would result in a high social cost of many unemployed workers. Big firms are also more likely to have unions, so that their workers are a stronger partner to negotiate with. For these reasons, the effect of employment size on the probability of getting restructuring aid vs. rescue aid is expected to be positive. From the government's point of view, however, there are big differences between public and private employment. For political economy reasons, governments might be interested in supporting public employment more than private employment. Frey and Pommerehne (1982) suggest that public employees have a higher participation rate in elections than the rest of the electorate and they support higher public expenditures. I use the variables SIZEPUBLIC $_{i}$ and SIZEPRIVATE $_{i}$ to distinguish between these two types of employment. While both positive, I expect the coefficient of private employment to be lower than the coefficient of public employment.

Benefits and costs of a bailout can vary dramatically across different sectors. A benefit of avoiding a bank bankruptcy is greater than in the case of a radio producer, even when both have the equal number of employees and the same ownership structure. The reason is that different type and size of externalities take place in different industries. In banking, not only bank employees lose the jobs, but also all businesses and individuals who had their accounts in the bank experience liquidity problems. An exit of a monopolist railway or an electricity distributor puts the whole economy into a danger of missing supply of their services. To capture such industry effects in the bailout policy equation, industry dummies are included. The variable $\operatorname{INFRASTR}_{i}$ equals one if firm $i$ is active in electricity, transport or financial services sector. A dummy for mining and manufacturing MINMAN $_{i}$ and a dummy for trade and services $\mathrm{SERVICE}_{i}$ are also included. Construction sector is left out as a reference category. 
To allow for cross-country differences in the bailout policy, dummies for five countries with the highest number of bailouts are added: Germany, Italy, France, Spain and Austria.

Table 1 indicated that in the year 2001 there was a flip in the proportions of rescue versus restructuring cases in the total subsidy number. This was most likely caused by political pressure at the European level to limit $R \& R$ aid. I include a variable RECENT equal 1 for subsidies granted in years 2001-2003 and 0 otherwise to account for possible time effects. I expect its estimated coefficient to be negative.

Marginal effects calculated for the average value of each variable are reported in table 11. Only 65 firms are used in the estimation, due to the fact that for the remaining 14 firms data on variables PUBLIC or employment size are missing. Two model specifications are presented: model 1 includes a total employment variable, while model 2 distinguishes between private and public employment.

The most significant marginal effect of $-68.5 \%$ is noted for the RECENT dummy. Firms subsidized after the year 2000 had a $68.52 \%$ lower chance of getting a restructuring subsidy than firms subsidized before 2001, ceteris paribus. This time effect is very strong, suggesting that bailout policy of governments has starkly changed in the recent years. The Lisbon Strategy announced in 2000 might be a driver of this change.

In both specifications the marginal effect of public ownership is statistically significant, however it has opposite signs. In the first model, the estimate reaches $29 \%$. In the second model, when I control for public and private employment separately, the effect of public ownership turns into $-78.1 \%$. The coefficients on both types of employment in model 2 are not significant. Still, p-values are not too high, so it is worth to interpret the marginal effects. The effect of private employment is negative and the effect of public employment is positive. How to think of these results? Public ownership alone does not increase chances for restructuring of aid, in contrary to what I expected, but it decreases these chances dramatically. What makes governments to spend more money on a bailout is actually public employment. The bigger public firms, the more likely restructuring aid. Employment in private firms has the opposite effect: the bigger a private firm, the less likely restructuring aid. That puts the argument of the prevention of job losses by 
Table 11: Estimates of marginal effects in industrial policy equation.

Dependent variable: SUBSIDY TYPE

\begin{tabular}{lcccc}
\hline Variable & Model 1 & p-values & Model 2 & p-values \\
\hline Firm characteristics & & & & \\
recent & $-0.685^{* * *}$ & 0.000 & $-0.685^{* * *}$ & 0.000 \\
public & $0.291^{*}$ & 0.057 & $-0.781^{*}$ & 0.060 \\
employment & -0.015 & 0.769 & & \\
sizeprivate & & & -0.091 & 0.205 \\
sizepublic & & & 0.081 & 0.329 \\
\hline Industry and country effects & & & & \\
infrastr & & & & \\
service & 0.218 & 0.377 & 0.123 & 0.679 \\
minman & 0.138 & 0.644 & -0.007 & 0.986 \\
Germany & -0.078 & 0.718 & -0.211 & 0.362 \\
Italy & -0.029 & 0.906 & -0.120 & 0.653 \\
France & -0.358 & 0.204 & $-0.515^{* *}$ & 0.042 \\
Spain & -0.305 & 0.372 & -0.463 & 0.138 \\
Austria & 0.050 & 0.851 & 0.014 & 0.962 \\
\hline N & -0.021 & 0.954 & -0.149 & 0.700 \\
pseudo-R2 & 65 & & 65 & \\
log-likelihood & 0.277 & & 0.307 & \\
chi2 & -30.936 & & -29.667 & \\
P & 23.739 & & 0.010 & \\
\hline Populaton : Cross-5ecton & 0.014 & & & \\
\hline
\end{tabular}

Population: Cross-section. ${ }^{* * *}(* *, *)$ denotes significance with $1 \%(5 \%, 10 \%)$ level in a twotailed Wald test.

bailouts in a doubtful light: public jobs are indeed supported more, but private jobs are disadvantaged.

Industry effects are highly insignificant. Among country effects, ITALY effect is significant, negative and rather large. Holding everything else constant, Italian firms were less likely to receive restructuring aid by about $51 \%$. The effect of France is close to significant and negative.

\section{Robustness}

Several robustness checks were performed. First, I redefine the variable RECENT as time trend, time squared, logarithm of time and annual or biannual dummies. The results were robust to these changes in sign and significance, but the model with the dummy 
had the highest joint-significance $\chi^{2}$ statistics. Therefore, I use RECENT as the best trend-indicator. Second, I estimate the equation using the logit model. Results are very similar as the probit estimates, suggesting the model's stability. Third, I use firms' age as a regressor. Age is measured in years between incorporation and the subsidy. The coefficient was insignificant in the regression and I decided to omit it because of numerous missing data in this variable.

\section{Privatization and old public firms}

Two important variables were perfectly predicting the subsidy choice. The first one is privatization. Privatization through bailouts means that a public firm was bailed out and, having received the subsidy, it was sold to private owners. Among all bailouts in years 1992-2003, 13 cases involved privatization. In a few cases, it was a requirement of the Commission in the approval process, but usually it was an initiative of the governments themselves. All 13 privatized firms got restructuring aid, implying that governments used substantial public funds to increase the value of the firm before the subsequent sale.

The second perfect predictor is age for state-owned firms. All 8 state-owned firms older than 100 years received exclusively restructuring aid, suggesting that governments supported old state-owned enterprizes.

\section{Summary}

Summing up, the time dummy has the most important impact on the governments' choice of the subsidy type. The estimates suggest that there was a structural change in the bailout policy: after the year 2000 governments chose rescue subsidies with a higher probability than restructuring aid, and the opposite is true for the earlier years. Stateowned firms get more restructuring aid mainly due to governments' preference to support public employment. Old state-owned firms and privatized firms were supported with only restructuring aid. Industrial sectors do not matter in the policy choice. Italian governments grant rescue aid somewhat more often than restructuring aid, while other governments do not have a special policy. 


\subsection{Endogenous subsidy choice}

In this section, the equations (10) and (11) are estimated simultaneously. Such an approach allows to correct for potential endogeneity of the subsidy type variable in the hazard equation. It is also a useful robustness check for the earlier results. Since estimators for a simultaneous model with a discrete-time hazard rate and a discrete-choice equation are to my knowledge not yet available, ${ }^{24} \mathrm{I}$ translate the hazard rate equation into a time-invariant binary outcome equation with one observation per firm. Then a bivariate probit estimator can be used. ${ }^{25}$ Duration dependence will be captured by adding the RECENT dummy.

The problem has a recursive nature: first the government decides which type of aid to grant and then, often a few years later, competition in the market forces the firms to exit or not. Therefore, a recursive bivariate probit specification seems appropriate: equation (11) explains the choice of the subsidy type, equation (10) explains the exit pattern depending on the subsidy type. ${ }^{26}$ The error terms in both equations could be correlated if there are unobservable factors that have an impact both on the subsidy type choice and the bankruptcy chances. Examples of such factors are the degree of firms' unionization or politicians having private information about firms. In the equations, I do not control for them directly, but they are taken into account using error terms. The econometric model which best fits this situation is a bivariate probit. I will therefore estimate the following model:

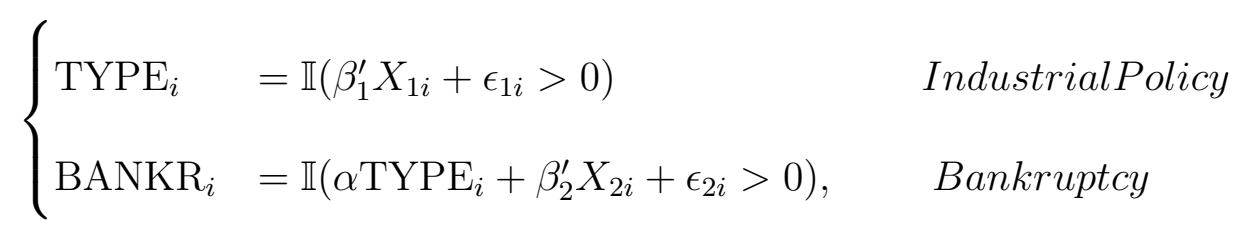

where $i$ is a firm index, vector $\left(\epsilon_{1}, \epsilon_{2}\right)$ has a bivariate normal distribution with mean zero, unit variances and $\operatorname{corr}\left(\epsilon_{1}, \epsilon_{2}\right)=\rho$. I apply maximum likelihood estimation method. Table

\footnotetext{
${ }^{24}$ This is left for future research. For a continuous-time hazard, a full information maximum-likelihood estimator was recently proposed by Boehmke et al. (2006).

${ }^{25}$ E.g. Wooldridge (2002), p. 477.

${ }^{26} \mathrm{~A}$ relevant remark here is that when governments choose the subsidy type, they possibly take exit probability into account, so that exit is also endogenous to the subsidy type. This issue is addressed in the subsection on the robustness of the results.
} 
12 presents the results. To facilitate a comparison, I include estimates of coefficients for several models. Models 1, 2, 4 and 5 are the results of single-equation probit estimations. Models 3 and 6 are the simultaneous specifications. In models 1-3 I control for employment in general, while in models 4-6 I distinguish between private and public employment.

The log-likelihood of the simultaneous models is higher than the sum of the loglikelihoods for the two equations estimated separately. The likelihood-ratio test indeed rejects the hypothesis that $\rho=0$ (for model 3: test statistics $\chi^{2}(1)=6.7956$, p-value 0.0091, for model 6: $\chi^{2}(1)=6.04384$, p-value 0.0140). According to Monfardini and Radice (2006), the likelihood-ratio test is the best method to test correlation of equations in case of small samples. Therefore, the results indicate that the equations in model (12) are correlated: unobserved factors influencing the chance for a restructuring aid have impact on the probability of bankruptcy.

Simultaneous estimation of both equations (models 3 and 6) does not change the coefficients' estimates too much, but suggests that the endogeneity issue is important for the results. In the bankruptcy equation of the simultaneous models, the coefficient on TYPE decreases when compared with the independent estimation. I therefore find that having separated the effect of beneficiaries characteristics on the industrial policy, restructuring aid is even more effective in preventing exit. If beneficiary characteristics erode the performance of restructuring aid, then firms receiving restructuring aid are not necessarily the most efficient ones.

In the industrial policy equation of model 3 , the positive coefficient of PUBLIC becomes smaller and less significant than in model 1, but its p-value of 0.157 is still not too high. This result suggests that public firms have a better chance to receive restructuring aid than private firms. The coefficient of PUBLIC in the bankruptcy equation is, however, not significant, suggesting that public firms are not better in survival than private firms. Therefore, governments' preference for public firms cannot be explained by these firms' higher probability of fulfilling bailouts' goals.

The effect of SIZEPRIVATE in model 6 becomes significant and much lower than in model 4. This implies that the bigger a private firm, the less likely restructuring aid. The 
Table 12: Estimates of coefficients in the bivariate probit model.

\begin{tabular}{|c|c|c|c|c|c|c|}
\hline & Model 1 & Model 2 & Model 3 & Model 4 & Model 5 & Model 6 \\
\hline \multicolumn{7}{|c|}{ Industrial policy } \\
\hline recent & $\begin{array}{l}-2.031^{* * *} \\
(0.003)\end{array}$ & & $\begin{array}{l}-1.921^{* * *} \\
(0.003)\end{array}$ & $\begin{array}{l}-2.040^{* * *} \\
(0.006)\end{array}$ & & $\begin{array}{l}-1.737^{* * *} \\
(0.003)\end{array}$ \\
\hline public & $\begin{array}{c}0.821^{*} \\
(0.077)\end{array}$ & & $\begin{array}{r}0.582 \\
(0.157)\end{array}$ & $\begin{array}{l}-2.532 \\
(0.250)\end{array}$ & & $\begin{array}{r}-3.220 \\
(0.118)\end{array}$ \\
\hline employment & $\begin{array}{r}-0.042 \\
(0.769)\end{array}$ & & $\begin{array}{r}-0.097 \\
(0.513)\end{array}$ & & & \\
\hline sizeprivate & & & & $\begin{array}{l}-0.246 \\
(0.204)\end{array}$ & & $\begin{array}{l}-0.438^{* *} \\
(0.026)\end{array}$ \\
\hline sizepublic & & & & $\begin{array}{r}0.219 \\
(0.326)\end{array}$ & & $\begin{array}{r}0.110 \\
(0.576)\end{array}$ \\
\hline infrastr & $\begin{array}{r}0.649 \\
(0.433)\end{array}$ & & $\begin{array}{r}0.883 \\
(0.259)\end{array}$ & $\begin{array}{r}0.346 \\
(0.694)\end{array}$ & & $\begin{array}{r}0.676 \\
(0.336)\end{array}$ \\
\hline service & $\begin{array}{r}0.409 \\
(0.679)\end{array}$ & & $\begin{array}{r}0.345 \\
(0.710)\end{array}$ & $\begin{array}{l}-0.019 \\
(0.986)\end{array}$ & & $\begin{array}{r}-0.279 \\
(0.782)\end{array}$ \\
\hline minman & $\begin{array}{l}-0.211 \\
(0.720)\end{array}$ & & $\begin{array}{r}-0.150 \\
(0.823)\end{array}$ & $\begin{array}{l}-0.581 \\
(0.377)\end{array}$ & & $\begin{array}{l}-0.395 \\
(0.562)\end{array}$ \\
\hline Germany & $\begin{array}{l}-0.077 \\
(0.906)\end{array}$ & & $\begin{array}{l}-0.207 \\
(0.726)\end{array}$ & $\begin{array}{l}-0.318 \\
(0.650)\end{array}$ & & $\begin{array}{l}-0.693 \\
(0.215)\end{array}$ \\
\hline France & $\begin{array}{r}-0.788 \\
(0.382)\end{array}$ & & $\begin{array}{r}-0.462 \\
(0.504)\end{array}$ & $\begin{array}{l}-1.237 \\
(0.207)\end{array}$ & & $\begin{array}{r}-1.072 \\
(0.151)\end{array}$ \\
\hline Italy & $\begin{array}{l}-0.931 \\
(0.227)\end{array}$ & & $\begin{array}{r}-1.130 \\
(0.108)\end{array}$ & $\begin{array}{l}-1.406 \\
(0.101)\end{array}$ & & $\begin{array}{l}-1.750^{* *} \\
(0.042)\end{array}$ \\
\hline Spain & $\begin{array}{r}0.139 \\
(0.854)\end{array}$ & & $\begin{array}{r}-0.114 \\
(0.857)\end{array}$ & $\begin{array}{r}0.037 \\
(0.962)\end{array}$ & & $\begin{array}{r}-0.386 \\
(0.568)\end{array}$ \\
\hline Austria & $\begin{array}{r}-0.055 \\
(0.953)\end{array}$ & & $\begin{array}{l}-0.221 \\
(0.781)\end{array}$ & $\begin{array}{l}-0.385 \\
(0.694)\end{array}$ & & $\begin{array}{r}-0.796 \\
(0.342)\end{array}$ \\
\hline \multicolumn{7}{|l|}{ Bankruptcy } \\
\hline \multicolumn{2}{|l|}{ Subsidy type } & $\begin{array}{l}-1.496^{* * *} \\
(0.001)\end{array}$ & $\begin{array}{l}-2.679^{* * *} \\
(0.000)\end{array}$ & & $\begin{array}{l}-1.491^{* * *} \\
(0.002)\end{array}$ & $\begin{array}{l}-2.611^{* * *} \\
(0.000)\end{array}$ \\
\hline recent & & $\begin{array}{l}-1.339^{* *} \\
(0.018)\end{array}$ & $\begin{array}{l}-1.845^{* * *} \\
(0.000)\end{array}$ & & $\begin{array}{l}-1.479^{* *} \\
(0.014)\end{array}$ & $\begin{array}{l}-2.026^{* * *} \\
(0.000)\end{array}$ \\
\hline public & & $\begin{array}{r}-0.053 \\
(0.894)\end{array}$ & $\begin{array}{r}0.301 \\
(0.412)\end{array}$ & & $\begin{array}{r}1.487 \\
(0.405)\end{array}$ & $\begin{array}{r}1.153 \\
(0.490)\end{array}$ \\
\hline employment & & $\begin{array}{r}-0.018 \\
(0.879)\end{array}$ & $\begin{array}{r}-0.028 \\
(0.798)\end{array}$ & & & \\
\hline sizeprivate & & & & & $\begin{array}{r}0.101 \\
(0.579)\end{array}$ & $\begin{array}{r}0.048 \\
(0.777)\end{array}$ \\
\hline sizepublic & & & & & $\begin{array}{l}-0.118 \\
(0.478)\end{array}$ & $\begin{array}{l}-0.081 \\
(0.603)\end{array}$ \\
\hline service & & $\begin{array}{r}-0.327 \\
(0.711)\end{array}$ & $\begin{array}{r}-0.498 \\
(0.512)\end{array}$ & & $\begin{array}{r}-0.180 \\
(0.841)\end{array}$ & $\begin{array}{r}-0.295 \\
(0.694)\end{array}$ \\
\hline minman & & $\begin{array}{r}0.296 \\
(0.460)\end{array}$ & $\begin{array}{r}0.130 \\
(0.720)\end{array}$ & & $\begin{array}{r}0.372 \\
(0.367)\end{array}$ & $\begin{array}{r}0.244 \\
(0.523)\end{array}$ \\
\hline $\bar{N}$ & 65 & 65 & 65 & 65 & 65 & 65 \\
\hline pseudo-R2 & 0.277 & 0.190 & & 0.307 & 0.200 & \\
\hline log-likelihood & -30.936 & -32.489 & -60.403 & -29.667 & -32.090 & -58.359 \\
\hline chi2 & 23.74 & 15.26 & 68.65 & 26.277 & 16.061 & 68.308 \\
\hline $\mathrm{p}$ & 0.013 & 0.000 & 0.018 & 0.010 & 0.025 & 0.000 \\
\hline
\end{tabular}

Population: Cross-section. P-values in parenthesis.

$* * *\left(* *,{ }^{*}\right)$ denotes significance with $1 \%(5 \%, 10 \%)$ level in a two-tailed Wald test. 
size of public firms is less important for the subsidy choice. This observation supports the earlier suggestion that governments discriminate between public and private employment to the disadvantage of the latter.

The coefficient's estimates for the RECENT variable in both equations of the simultaneous models are significant. Compared with the single-equation specifications, they change their magnitudes rather moderately. Thus, timing and duration play an important role in both processes. In the exit process, firms subsidized only in the last three years had lower bankruptcy probability. Regarding the industrial policy, rescue aid was more likely in the last three years.

\section{Robustness}

If governments condition the decision about the subsidy type on the chances of the firm in trouble to survive, the variable BANKR should be present in the second equation of the model (12). However, a simultaneous equation model with two endogenous discrete variables one being a function of the other suffers from logical inconsistency (Maddala, 1983, p. 117.). I address this issue by estimating a "reverse" recursive model, in which the probability of bankruptcy is a function of exogenous variables only and the subsidy type choice is a function of the bankruptcy chances and a set of exogenous variables: ${ }^{27}$

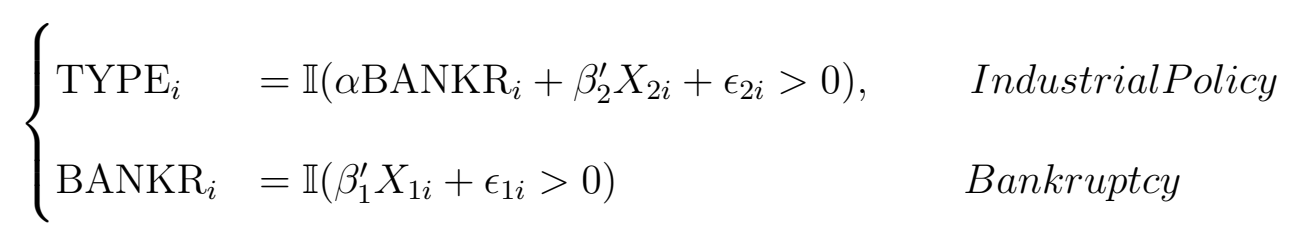

However, this regression does not go through the basic diagnostics. In the specification with one employment variable, the likelihood ratio test cannot reject the hypothesis that $\rho=0\left(\chi^{2}(1)=0.000293, \mathrm{p}\right.$-value 0.9863$)$. The hypothesis that the coefficients are jointly insignificant cannot be rejected either (Wald $\chi^{2}(17)=20.24$, p-value 0.262). The specification with separated public and private employment gives similar results. The model (13) is without any doubt inferior to the model (12).

\footnotetext{
${ }^{27}$ This approach is used by Beck (2004).
} 


\section{Conclusions}

The results in this paper contribute to the understanding of the European bailout policy used in the past. Increasing bankruptcy rate and a relatively high share of failing bailouts suggest scope for improvements in this policy. Soft-budget constraints and moral hazard are of particular concern. A simple and practical solution to remedy this problem was already suggested by Nitsche and Heidhues (2006) and I strongly support it: bailouts should be limited to firms in formal bankruptcy. In this way, incentives of managers to apply for a bailout will be reduced. Chapter 11 protection in the U.S. provides an example of this approach.

Empirical evidence on bailouts of state-owned firms shows weaknesses of using state aid as an instrument to prevent bankruptcy of firms. State-owned firms are overrepresented among $R \& R$ aid beneficiaries and receive restructuring aid more often than their private competitors. At the same time, they do not go bankrupt less often. Clearly, governments favor public firms in the bailout decisions. Such a policy is almost certain to create soft-budget constraints for state-owned firms.

An important issue not addressed in this paper is the selection process to the $R \& R$ subsidy program. Far more firms go bankrupt than are bailed out. An empirical analysis of the determinants of the choice to bailout or not would provide more detailed evidence on the bailout policies in member states. Another interesting research problem is an empirical analysis of balance sheet data for $\mathrm{R} \& \mathrm{R}$ aid beneficiaries before aid and during the restructuring process. Going to the accounting data would allow to account for the amount and form of aid and would provide evidence on the sources of distress, how the aid was spent and how many jobs it saved. These are issues left for further research. 


\section{References}

Arindam Bandopadhyaya. An estimation of the hazard rate of firms under Chapter 11 protection. The Review of Economics and Statistics, 76(2):346-50, May 1994.

Jonathan Beck. Fixed, focal, fair? Book prices under optional resale price maintenance. CIC Working Papers SP II 2004-15, Wissenschaftszentrum Berlin, December 2004.

Robin Boadway, Nicolas Marceau, and Maurice Marchand. Time-consistent subsidies to unlucky firms. European Journal of Political Economy, 11:619 - 634, 1995.

Frederick J. Boehmke, Daniel S. Morey, and Megan Shannon. Selection bias and continuous-time duration models: Consequences and a proposed solution. American Journal of Political Science, 50(1):192-207, 2006.

J. Buckley and C. Westerland. Duration dependence, functional form, and corrected standard errors: Improving EHA models of state policy diffusion. State Politics and Policy Quarterly, 4(1):92-111, 2004.

Rohan Chindooroy, Patrice Muller, and Giovanni Notaro. Company survival following rescue and restructuring state aid. Working Paper Ref: 2005-01, London Economics, 2005.

Oscar Couwenberg. Survival rates in bankruptcy systems: Overlooking the evidence. European Journal of Law and Economics, 12(3):253-273, November 2001.

Economic Research Unit Creditreform. Insolvencies in Europe 2001/2002. A survey, Creditreform, 2002.

London Economics. Ex-post evaluation of the impact of rescue and restructuring aid on the international competitiveness of the sectors affected by such aid. Report for the European Commission, 2004.

Bruno S. Frey and Werner W. Pommerehne. How powerful are public bureaucrats as voters? Public Choice, 38(3):253-262, January 1982.

Hans W. Friederiszick, Lars-Hendrik Röller, and Vincent Verouden. European state aid control: an economic framework. In Paolo Buccirossi, editor, Advances in the Economics of Competition Law. MIT Press, 2006.

Ela Głowicka. Bailouts in a common market: a strategic approach. CIC Working Papers SP II 2005-20, Wissenschaftszentrum Berlin, November 2005.

James J. Frey Heckman. Micro data, heterogeneity, and the evaluation of public policy: Nobel lecture. Journal of Political Economy, 109(4):673-748, 2001.

Joseph P. Hughes and Loretta J. Mester. A quality and risk-adjusted cost function for banks: evidence on the "too-big-to-fail" doctrine. Journal of Productivity Analysis, 1993.

Stephen P. Jenkins. Survival analysis. Unpublished manuscript, Institute for Social and Economic Research, University of Essex, Colchester, UK, 2004. 
George G. Kaufman. Too big to fail in U.S. banking: Quo vadis? Mimeo, Loyola University Chicago and Federal Reserve Bank of Chicago, 2003.

Kai Li. Bayesian analysis of duration models: an application to Chapter 11 bankruptcy. Economics Letters, 63(3):305-312, June 1999.

Kai Li. An empirical examination of U.S. firms in Chapter 11 bankruptcy. Working paper, UBC, 1998.

Justin Yifu Lin, Fang Cai, and Zhou Li. Competition, policy burdens, and state-owned enterprise reform. American Economic Review, 88(2):422-27, May 1998.

G. S. Maddala. Limited-Dependent and Qualitative Variables in Econometrics. Cambridge University Press, 1983.

C. Monfardini and R. Radice. Testing exogeneity in the bivariate probit model: a monte carlo study. Mimeo, University of Bologna, 2006.

Peter J. Neary. Cost asymmetries in international subsidy games: should governments help winners or losers? Journal of International Economics, 37:197-218, 1994.

Phedon Nicolaides and Mihalis Kekelekis. When do firms in trouble escape from state aid rules? European State Aid Law Quarterly, 4(1):17 -26, January 2005.

Reiner Nitsche and Paul Heidhues. Study on methods to analyse the impact of state aid on competition. European Economy, Economic Papers 244, European Commission, 2006.

Lars-Hendrik Röller and Zhentang Zhang. Bundling of social and private goods and the soft budget constraint problem. Journal of Comparative Economics, 33(1):47-58, March 2005.

Ilya R. Segal. Monopoly and soft budget constraint. RAND Journal of Economics, 29 (3):596-609, Autumn 1998.

Tyler Shumway. Forecasting bankruptcy more accurately: A simple hazard model. Journal of Business, 74(1):101-24, January 2001.

European Union. Community guidelines on state aid for rescuing and restructuring firms in difficulty. Official Journal of the European Union, C 244/02, 2004.

European Union. Consolidated versions of the Treaty on European Union and of the Treaty establishing the European Community. Official Journal of the European Union, C 325, 2002.

V. Vig. Bailout, bankruptcy and who bails out the bailout? European State Aid Law Quarterly, 4:551-553, 2004.

Jeffrey M. Wooldridge. Econometric Analysis of Cross Section and Panel Data. MIT Press, 2002. Second Edition. 


\section{A Industry classification}

NACE (Rev.1) comes from the French term Nomenclature statistique des Activités économiques dans la Communauté Européenne (Statistical classification of economic activities in the European Community) and is a European industry classification system. At the 2-digit level NACE is fully compatible with ISIC.

Table 13: Two-digit NACE classification.

\begin{tabular}{lr}
\hline Industry & NACE codes \\
\hline Mining & $12-14$ \\
Manufacturing & $15-37$ \\
Electricity and water supply & $40-41$ \\
Construction & 45 \\
Trade & $50-52$ \\
Transport & $60-64$ \\
Financial services & $65-67$ \\
Other services & $55,70-99$ \\
\hline
\end{tabular}

\section{B Data set description}

The data set contains information on $R \& R$ subsidy cases in the European Union in years 1995-2003. It is a unique data set created from four data sources. Subsidy information comes from the texts of the European Commission's decision and the report by London Economics (2004) provided by Competition Directorate General. Financial and ownership information on firms from sectors other than financial comes from AMADEUS database provided by Bureau van Dijk Electronic Publishing. For firms from the financial sector I use annual reports, if available. Other firm-level data comes from newspapers.

I construct three data sets. A cross-section of decisions is a set with a decision as a unit of observation, it entails 86 observations in total. A cross-section of firms is a set with a firm receiving $R \& R$ aid as a unit of observation, it entails 79 observations in total. Finally, a panel is a two-dimensional set with aid receivers observed across time.

I build a panel based on the following principles. Subjects in the panel are all R\&R subsidy beneficiaries, whose surviving status is known in at least one year. This amounts 
to 75 firms. Each firm was observed from the year it was bailed out until 2003 or its earlier bankruptcy. Bankruptcy is defined as ceasing the major activity of a firm. 22 R\&R subsidy beneficiaries went bankrupt in the time between receiving the subsidy and the end of 2003. The remaining 53 firms were observed until the year 2003 without going bankrupt. Following the survival literature, I call them right-censored or lost, but in my context they are simply firms, which from the subsidy year up to 2003 stayed in operations. All in all, for the survival analysis I have an unbalanced panel of 409 observations, with 75 firms observed during the years 1992-2003.

Table 14: Variables used and their sources.

\begin{tabular}{|c|c|c|}
\hline Variable & Definition & Source \\
\hline Subsidy year & Year of subsidy transfer & decision texts \\
\hline Subsidy type & Rescue or restructure & decision texts \\
\hline Country & $\begin{array}{l}\text { Country of the subsidizing gov- } \\
\text { ernment }\end{array}$ & decision texts \\
\hline State-owned & $\begin{array}{l}\text { Dummy equal to } 1 \text { if the state } \\
\text { owns more than } 50 \% \text { of shares }\end{array}$ & decision texts, AMADEUS, LE report \\
\hline Year of incorporation & $\begin{array}{l}\text { Year in which the firm started op- } \\
\text { erations }\end{array}$ & AMADEUS, LE report \\
\hline Year of bankruptcy & $\begin{array}{l}\text { Year in which the firm went } \\
\text { bankrupt }\end{array}$ & LE report, newspapers \\
\hline Industry & $\begin{array}{l}\text { Industry with the highest share in } \\
\text { the revenue, based on NACE (see } \\
\text { table } 13 \text { ) }\end{array}$ & AMADEUS, LE report \\
\hline For sale & $\begin{array}{l}\text { Dummy equal to } 1 \text { if after get- } \\
\text { ting the subsidy the firm was } \\
\text { sold. }\end{array}$ & LE report, newspapers \\
\hline Employment & Number of employees & AMADEUS, LE report, annual reports \\
\hline
\end{tabular}

\section{Basic definitions in survival analysis}

This appendix is based on Jenkins (2004). Survival analysis deals with a time-to-event random variable called also spell length, spell duration or survival length. The researcher is interested in the distribution of time needed to observe the event. The event can be anything, but in the first applications it was death and for this reason it is often referred to as a failure. Examples of the applications include examination of the effectiveness of 
medicines by comparing life lengths of treated and non-treated patients, failure rates for machines in the production process, bankruptcy rates, marriage patterns etc. In each case, the failure is an event of transition from one state to another: death, bankruptcy, marriage.

Assume first that time is continuous. $T$ is the spell length, the random variable with the distribution function $f(t)$ and a c.d.f. $F(t)$ (called also the failure function). The survivor function is the probability of survival $S(t)=\operatorname{Pr}(T>t)=1-F(t)$. The continuous hazard rate is defined as

$$
\theta(t)=\frac{f(t)}{1-F(t)}
$$

and can be interpreted as an instantaneous "probability" of failure in time $t$ conditional on surviving until $t$. It is not a real probability, however, since its values are not necessarily from the range $[0,1]$.

The basic relationships between the failure, survivor and hazard functions can be derived as follows.

$$
\begin{aligned}
& \theta(t)=\frac{f(t)}{1-F(t)}=\frac{\partial(1-F(t)) / \partial t}{1-F(t)} \\
= & \frac{\partial[-\ln (1-F(t))]}{\partial t}=\frac{\partial[-\ln (S(t))]}{\partial t} .
\end{aligned}
$$

Now integrate both sides

$$
\int_{0}^{t} \theta(u) d u=-\left.\ln (1-F(t))\right|_{0} ^{t}
$$

and use $F(0)=0$ and $\ln 1=0$ to get

$$
\begin{array}{r}
\ln [1-F(t)]=\ln (S(t))=-\int_{0}^{t} \theta(u) d u \\
S(t)=\exp \left(-\int_{0}^{t} \theta(u) d u\right) \\
S(t)=\exp [-H(t)]
\end{array}
$$


where $H(t)=\int_{0}^{t} \theta(u) d u=-\ln (S(t))$ is an integrated hazard function. The final relationship is just an observation that

$$
\begin{array}{r}
H(t) \geq 0, \\
\frac{\partial H(t)}{\partial t}=\theta(t) .
\end{array}
$$

Now suppose the time is discrete. Discrete time means that the real timeline is divided into intervals:

$$
\left[0=a_{0}, a_{1}\right],\left(a_{1}, a_{2}\right],\left(a_{2}, a_{3}\right], \ldots\left(a_{k-1}, a_{k}=\infty\right]
$$

The probability of failure at the end of interval $j$ is then $F\left(a_{j}\right)$. The survivor function at the end of the interval $j$ is $S\left(a_{j}\right)=\operatorname{Pr}\left(T>a_{j}\right)=1-F\left(a_{j}\right)$.

The discrete hazard rate for the interval $j$ is defined as the probability of failure in the interval $j$, conditional on surviving until the beginning of the interval $j$

$$
\begin{array}{r}
h\left(a_{j}\right)=\operatorname{Pr}\left(a_{j-1}<T \leq a_{j} \mid T>a_{j-1}\right) \\
=\frac{\operatorname{Pr}\left(a_{j-1}<T \leq a_{j}\right)}{\operatorname{Pr}\left(T>a_{j-1}\right)} \\
=\frac{S\left(a_{j}\right)-S\left(a_{j-1}\right)}{S\left(a_{j-1}\right)} \\
=1-\frac{S\left(a_{j}\right)}{S\left(a_{j-1}\right)} .
\end{array}
$$

Note that the discrete hazard rate is a proper (conditional) probability. 